Proceedings of SALT 26: 566-583, 2016

\title{
Realis and non-realis modalities in Daakie (Ambrym, Vanuatu)*
}

\author{
Manfred Krifka \\ Humboldt-Universität Berlin \\ \& Zentrum für Allgemeine Sprachwissenschaft (ZAS) Berlin
}

\begin{abstract}
This paper analyzes the system of modality marking in Daakie, an Austronesian (Oceanic) language spoken on Ambrym (Vanuatu). Daakie has a fiveway distinction that expresses both temporal and modal notions. In addition to a realis marker there is a potentialis marker for events that are expected to happen, a distal marker for temporally or modally remote events, a realis negation, and a potentialis negation. These markers are used in main and dependent clauses, where they express factive and negative interpretations.
\end{abstract}

Keywords: modality, realis, presupposition, negation, factivity, Austronesian, Oceanic

\section{Introduction}

In this paper I will describe and analyze the modality system of the language Daakie, also known as Port Vato (ISO 639-3 ptv, Glottolog port1286). Daakie is spoken by about 1000 persons on the southern coast of the island of Ambrym, Vanuatu; it is an Austronesian, specifically Oceanic, language belonging to the Central Vanuatu subgroup. The data is based on documentary field work from 2010 to 2016, resulting in about 8 hours of transcribed spoken materials, and additional written texts and translations by native speakers. There is no grammatical description of Daakie, but there is a comprehensive grammar of the closely related language Daakaka spoken immediately to the West (von Prince 2015); a preliminary analysis of the modality system was presented by Krifka (2012). This system is typical for Oceanic languages in Melanesia in exhibiting a Realis-Irrealis distinction (see de Haan 2012 for a typological overview of such systems).

Finite verbs in Daakie are preceded by a modal marker that is suffixed to the subject marker that expresses agreement with the subject in person and number

* I gratefully acknowledge financial support by the VolkswagenStiftung (DoBeS), by the Bundesministerium für Bildung und Forschung, and the Senate of Berlin. Thanks in particular to Kilu von Prince for numerous discussions, and to audience at AFLA 2012 at Harvard, MPI Nijmegen 2013, SIAS Summer Institute "The investigation of linguistic meaning", Berlin 2015, University of Texas at Austin, 2015, and University College London, December 2015. I am also very grateful to the developers of the ELAN audio and video annotation software at the MPI for Psycholinguistics, Nijmegen, and of the Toolbox software, SIL International.

(C) 2016 Krifka 
$\left(1^{\text {st }} / 2^{\text {nd }} / 3^{\text {rd }}\right.$ and $1+2^{\text {nd }}$ person; singular, dual, paucal, and plural number $)$. In the $3^{\text {rd }}$ person singular, there is no subject agreement, and the modal marker surfaces in a bare form, which varies depending on the phonological shape of the following verb. There are five modal markers: Realis $(-m)$, Realis Negation (-re), Potentialis $(-p$ or $b-)$, Potentialis Negation $(-n)$ and Distal $(-t)$.

\section{Modeling assumptions}

I assume a frame of branching times/worlds (cf. Dowty 1977), as this captures the temporal and the modal use of the modal markers. It consists of a set I of worldtime indices $i, i^{\prime}$ etc. that are partially ordered by a relation $\leq$ of temporal precedence; $i \leq i^{\prime}$ means $i=i^{\prime}$ or $i$ precedes $i^{\prime}$, and $i \sim i^{\prime}$ holds iff $i$ and $i^{\prime}$ are indices on the same branch. Linear intervals of indices are called histories.

(1) a. I: set of world-time indices, with partial order $\leq$ (precedence)

b. $i \sim i^{\prime}$ iff $i \leq i^{\prime}$ or $i^{\prime} \leq i$

c. $\mathrm{h} \subseteq \mathrm{I}$ is a history iff $\forall \mathrm{i}, \mathrm{i}^{\prime}\left[\left[\mathrm{i} \in \mathrm{h} \wedge \mathrm{i}^{\prime} \in \mathrm{h} \rightarrow \mathrm{i} \sim \mathrm{i}^{\prime}\right] \wedge \forall \mathrm{i}^{\prime \prime}\left[\mathrm{i} \leq \mathrm{i}^{\prime \prime} \leq \mathrm{i}^{\prime} \rightarrow \mathrm{i}^{\prime \prime} \in \mathrm{h}\right]\right]$

The semantic representation of the modal markers will make use of potentially undefined values, which require a trivalent logic with values true 1 , false 0 , and undefined *. We define operators for truth, definedness and semantic presupposition, where the latter is understood as condition for definedness. ${ }^{1}$
a. ! $\Phi==_{\text {def }} 1$ if $\Phi=1,=_{\text {def }} 0$ iff $\Phi=0$ or $\Phi=*$ ('it is true that $\Phi$ ')
b. $\$ \Phi=$ def 1 if $\Phi=1$ or $\Phi=0,=_{\text {def }} 0$ if $\Phi=*$ (' $\Phi$ is defined')
c. : $\Phi==_{\text {def }} 1$ if $\Phi=1,=_{\text {def }} *$ iff $\Phi=0$ or $\Phi=*$ ('it is presupposed that $\Phi$ ')

Basic formulas are defined; undefinedness arises due to the presupposition operator. For ordinary connectives, I assume Kleene's weak trivalent logic, which states that $\neg \Phi$ is undefined iff $\Phi$ is undefined, and $[\Phi \wedge / \vee / \rightarrow / \leftrightarrow \Psi]$ is undefined iff $\Phi$ or $\Psi$ are undefined. I will write [: $\pi \Phi]$ for [: $\pi \wedge \Phi]$, i.e. for a formula $\Phi$ with presupposition $\pi$. We have the following rules for undefinedness:
a. $\neg[: \pi \Phi] \equiv[: \pi \neg \Phi]$
b. $\left[: \pi \Phi \wedge / \vee / \rightarrow / \leftrightarrow: \pi^{\prime} \Phi^{\prime}\right] \equiv\left[:\left[\pi \wedge \pi^{\prime}\right] \Phi \wedge / \vee / \rightarrow / \leftrightarrow \Phi^{\prime}\right]$
c. $:: \Phi \equiv: \Phi$
d. $[: \Phi \Phi] \equiv: \Phi$
e. $!: \Phi \equiv ! \Phi$
f. $! \Phi \equiv \Phi$, if $\Phi$ is undefined, i.e. contains no part : $\Psi$

I assume restricted quantification, which ensures that undefinedness has an effect only in the scope $\Psi$, not in the restrictor $\Phi$, where it is treated as falsity:

1 This notion of undefinedness cannot cover the notion of pragmatic presupposition, as being es tablished in the common ground. In particular, Kleene's weak projection rules do not predict the projection rules of pragmatic presuppositions (cf. Beaver 1997). 
Realis and non-realis modality

(4) a. $\forall \mathrm{x}: \Phi(\mathrm{x})[\Psi(\mathrm{x})]={ }_{\text {def }} \forall \mathrm{x}[! \Phi(\mathrm{x}) \rightarrow \Psi(\mathrm{x})]$

b. $\exists \mathrm{x}: \Phi(\mathrm{x})[\Psi(\mathrm{x})]={ }_{\text {def }} \exists \mathrm{x}[! \Phi(\mathrm{x}) \wedge \Psi(\mathrm{x})]$

This results in the projection rules (5), where a presupposition of the nuclear scope turns into a universal presupposition for the restrictor, both for $\forall$ and $\exists$.
a. $\forall \mathrm{x}: \Phi(\mathrm{x})[: \pi(\mathrm{x}) \Psi(\mathrm{x})] \equiv[: \forall \mathrm{x}: \Phi(\mathrm{x})[\pi(\mathrm{x})] \forall \mathrm{x}: \Phi(\mathrm{x})[\Psi(\mathrm{x})]]$
b. $\exists \mathrm{x}: \Phi(\mathrm{x})[: \pi(\mathrm{x}) \Psi(\mathrm{x})] \equiv[: \forall \mathrm{x}: \Phi(\mathrm{x})[\pi(\mathrm{x})] \exists \mathrm{x}: \Phi(\mathrm{x})[\Psi(\mathrm{x})]]$

\section{Realis $-m / m(w) V$}

Realis is the most frequent modality in the text corpus. In main clauses, it is used to refer to ongoing, cf. (6), or past, cf. (7), events and states. ${ }^{2}$

(6) Obwet an vu mi myuu mo do taro CL2-3S introduced RE grow REslow

'The Fiji taro is growing slow', speaker is pointing at a plant (Jemis2.054)

(7) Meerin na-m mee o-ke-lé na-m lehe

long.time.ago 1S-RE come LOC-CP-PROX 1S-RE look

'Long time ago I came, I looked', narrative (Bong2.027)

In embedded clauses, realis is used when the embedded clause is taken to be true by the speaker. Such factive clauses have a complementizer $k e$. This is illustrated with complement clauses (perception, cf. (8), and epistemic, cf. (9)) and adjunct clauses (reason, cf. (10) and temporal, cf. (11)).

(8) kolo-m lehe ke m-aloo em mwe sanga ten 3DU-re see [CP.RE CL3-DU house RE bad very] 'The two saw that their house was very bad.', trad. story (Bong4.049)

(9) kolo-re kiibele ke kolo-m du taali lii-byak kiye 3DU-RNEG know [CP.RE 3DU-RE stay other.TR tree=nambanga DEF.3SG] 'The two did not know that they were staying at opposite sides of the nambanga tree', sanddrawing story (Ilson 3.005)

2 I follow the orthography of Daakie that was developed in the documentation project. Glosses: RE realis, POT potentialis, RNEG realis negation, PNEG potentialis negation, DIST distal, FUT future, first person, 2 second person, 3 third person, $1+2$ first/second person inclusive, SG singular, DU dual, PC paucal, PL plural, CL1/2/3 possessive classes, CP and CP.RE realis complemetizer, CP.NRE nonrealis complementizer, LOC reference to location, PROX proximate, COP copula, TR transitive, REDUP reduplication, NOMIN nominalizer, NRE nonrealis, IDEF indefinite, PART partitive. The references are to the corpus of Daakie, mostly transcribed recordings of video recordings that are available on request and that will be made accessible at the TLA database at https://tla.mpi.nl/. 
(10) na-m pwet hospital byen ke popat mwe te ye-k 1SG-RE stay hospital [because CP.RE pig RE cut leg-1SG] 'I stayed in the hospital because the pig cut my leg.', pers. story (Boa1.079)

(11) bili ke la-m seene meleh me van mo sók=tahe nane popat [time CP.RE 3PL-RE throw.TR food RE go] RE take=again from pig 'When they threw food inside he took it again from the pigs.' (PSak2.025)

The complementizer ke also occurs in relative clauses, as in (12), which also illustrates a potentialis clause with a non-realis complementizer, $\mathrm{ka}$.

$$
\begin{array}{lllll}
\text { pune }=n \quad k e \text { na-m longbini } & k a & \text { na-p } & \text { pune } \\
\text { tell=NOMIN CP.RE } 1 \mathrm{SG}-\mathrm{RE} & \text { want } & \text { CP.NR } & 1 \mathrm{SG}-\mathrm{POT} & \text { tell } \\
\text { 'the story that I want to tell', trad. story (Bong1.092) } &
\end{array}
$$

Realis clauses make a new contribution to the common ground as root clauses but signal factivity as embedded clauses. I propose that they contain a realis presupposition, viz. they mark that their host proposition is in fact true. It might seem that then they cannot be used in an informative way. However, notice that a speaker has a choice of either asserting a realis clause, or not to assert it, and so its assertion is informative. What a speaker cannot do is to assert its negation, as this would conflict with its presupposition; cf. Section 4 for realis negation.

I will discuss the different modalities with variations of the clause (13), for which I assume the indicated syntactic structure. I assume that the subject of the vP is moved to the specifier of the IP which carries a modal marker in its head, a position at which agreement is expressed. The $\mathrm{CP}$ is headed by an existential clo sure operator $\exists$; in other clause types there is a complementizer. I also assume a ForceP at which speech-act operators like Assertion are realized.

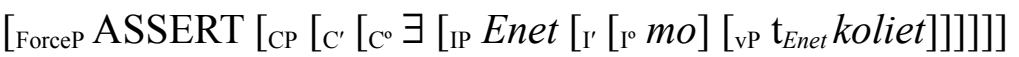
'Enet is singing.', 'Enet sang.'

Interpretations of expressions are with respect to a context index c. Subject movement is disregarded; the subject is interpreted in the position of its trace.

(14) a. $\mathbb{[}\left[{ }_{\mathrm{vP}} \mathrm{t}_{\text {Enet }}\right.$ koliet $] \rrbracket(\mathrm{c})=\lambda \mathrm{i}[$ Enet sings at $\mathrm{i}],=\varphi$, host proposition

b. $\mathbb{[}\left[\mathrm{I}^{\circ}-m\right] \rrbracket(\mathrm{c})=\lambda \mathrm{i} \lambda \mathrm{i}^{\prime} \lambda \mathrm{p}\left[: \exists \mathrm{i}^{\prime}\left[\mathrm{i}^{\prime} \leq \mathrm{c} \mathrm{p}\left(\mathrm{i}^{\prime}\right)\right]\left[\mathrm{i}^{\prime} \leq \mathrm{i} \mathrm{p}(\mathrm{i})\right]\right]$, modal operator

c. $\mathbb{[}\left[\right.$ IP Enet [mo [t $\mathrm{t}_{\text {Enet }}$ koliet $\left.\left.]\right]\right] \rrbracket(\mathrm{c})$, modalized propositional relation $=\lambda \mathrm{i} \lambda \mathrm{i}^{\prime}\left[\mathbb{[}\left[\mathrm{I}^{\circ} m o \rrbracket(\mathrm{c})(\mathrm{i})\left(\mathrm{i}^{\prime}\right)\left(\mathbb{L}\left[{ }_{\mathrm{vp}} \mathrm{t}_{\text {Enet }} k o l i e t\right] \rrbracket(\mathrm{c})(\mathrm{i})\right)\right]\right.$ $=\lambda \mathrm{i} \lambda \mathrm{i}^{\prime}\left[: \exists \mathrm{i}^{\prime}\left[\mathrm{i}^{\prime} \leq \mathrm{c} \varphi\left(\mathrm{i}^{\prime}\right)\right]\left[\mathrm{i}^{\prime} \leq \mathrm{i} \varphi\left(\mathrm{i}^{\prime}\right)\right]\right]$

d. $\llbracket \exists \rrbracket(c)=\lambda \mathrm{i} \lambda \mathrm{p} \exists \mathrm{i}^{\prime}\left[\mathrm{p}\left(\mathrm{i}^{\prime}\right)\right]$

e. $\mathbb{[}\left[\mathrm{CP} \exists\left[\right.\right.$ [IP Enet $\left[\mathrm{mo}\left[\mathrm{t}_{\text {Enet }}\right.\right.$ koliet $\left.\left.\left.\left.]\right]\right]\right]\right](\mathrm{c})$, modalized proposition $=\lambda \mathrm{i}\left[\mathbb{[} \exists \rrbracket(\mathrm{c})(\mathrm{i})\left(\mathbb{[}\left[\right.\right.\right.$ Ir Enet $\left[\right.$ mo $\left[\mathrm{t}_{\text {Enet }}\right.$ koliet $\left.\left.\left.\left.\left.]\right]\right]\right](\mathrm{c})(\mathrm{i})\right)\right]$ $=\lambda \mathrm{i}\left[: \exists \mathrm{i}^{\prime}\left[\mathrm{i}^{\prime} \leq \mathrm{c} \varphi\left(\mathrm{i}^{\prime}\right)\right] \exists \mathrm{i}^{\prime}\left[\mathrm{i}^{\prime} \leq \mathrm{i} \varphi\left(\mathrm{i}^{\prime}\right)\right]\right]$ 
Realis and non-realis modality

Semantic composition is by functional application, whereby indices are projected. Application of a modal operator at the IP level leads to a propositional re lation between an index $i$ to an index $i^{\prime}$ at which the host proposition is true; I will call $i$ " "event index" and $i$ "reference index". In the case of realis, it is presupposed that the host proposition is true at an index at or before the context c, and that the event index is situated at or before the reference index.

Assertion is modeled as an operation on common grounds $\mathrm{C}$, the set of indices compatible with the mutual shared knowledge of the interlocutors. To assert a $\mathrm{CP}$ at $\mathrm{C}$ amounts to restricting $\mathrm{C}$ to the indices $\mathrm{c}$ for which the $\mathrm{CP}$ relation holds:

$$
\llbracket \operatorname{ASSERT} \rrbracket(C)=\lambda \mathrm{r} \lambda \mathrm{c}[\mathrm{C}(\mathrm{c}) \wedge ! \mathrm{r}(\mathrm{c})(\mathrm{c})]
$$

$$
\begin{aligned}
& \mathbb{\llbracket}[\text { Forcep ASSERT [cp Enet mo koliet }]] \rrbracket(\mathrm{C}) \\
& =\llbracket \text { ASSERT } \rrbracket(\mathrm{C})(\mathbb{[}[\mathrm{cP} \text { Enet mo koliet }] \rrbracket) \\
& =\lambda \mathrm{r} \lambda \mathrm{c}[\mathrm{C}(\mathrm{c}) \wedge ! \mathrm{r}(\mathrm{c})(\mathrm{c})]\left(\lambda \mathrm{c} \lambda \mathrm{i}\left[: \exists \mathrm{i}^{\prime}\left[\mathrm{i}^{\prime} \leq \mathrm{c} \varphi\left(\mathrm{i}^{\prime}\right)\right] \exists \mathrm{i}^{\prime}\left[\mathrm{i}^{\prime} \leq \mathrm{i} \varphi\left(\mathrm{i}^{\prime}\right)\right]\right]\right) \\
& =\lambda \mathrm{c}\left[\mathrm{C}(\mathrm{c}) \wedge !\left[: \exists \mathrm{i}^{\prime}\left[\mathrm{i}^{\prime} \leq \mathrm{c} \varphi\left(\mathrm{i}^{\prime}\right)\right] \exists \mathrm{i}^{\prime}\left[\mathrm{i}^{\prime} \leq \mathrm{c} \varphi\left(\mathrm{i}^{\prime}\right)\right]\right]\right] \\
& =\lambda \mathrm{c}\left[\mathrm{C}(\mathrm{c}) \wedge ! \exists \mathrm{i}^{\prime}\left[: \mathrm{i}^{\prime} \leq \mathrm{c} \varphi\left(\mathrm{i}^{\prime}\right)\right]\right], \text { cf. }(3 \mathrm{~d}, \mathrm{e}) \\
& =\lambda \mathrm{c}\left[\mathrm{C}(\mathrm{c}) \wedge \exists \mathrm{i}^{\prime}\left[\mathrm{i}^{\prime} \leq \mathrm{c} \wedge \varphi\left(\mathrm{i}^{\prime}\right)\right]\right], \mathrm{cf} .(3 \mathrm{f})
\end{aligned}
$$

The truth operator ! in the definition of ASSERT prevents $\mathrm{C}$ from becoming undefined. If for all $\mathrm{c}^{\prime}$ it holds that $\mathrm{C}\left(\mathrm{c}^{\prime}\right) \neq *$, then it will also hold that for all $\mathrm{c}^{\prime}$ that $\lambda \mathrm{c}[\mathrm{C}(\mathrm{c}) \wedge ! \Phi(\mathrm{c})]\left(\mathrm{c}^{\prime}\right) \neq *$, as $! \Phi\left(\mathrm{c}^{\prime}\right) \neq *$. Notice that the assertion (16) is informative: $\mathrm{C}$ is restricted to those indices $\mathrm{c}$ such that Enet sings at $\mathrm{c}$ or before $\mathrm{c}$.

Let us now consider realis embedded clauses, with example (17), where the complementizer $k e$ is the head of the CP. I assume that ke expresses existential closure, $\exists$; as $k e$ is restricted to realis contexts, it expresses a realis presupposition, cf. (18). It matches with the realis proposition, cf. (19).

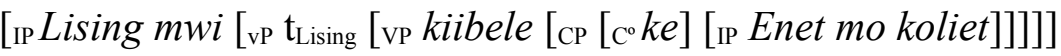
'Lising knows/knew that Enet is/was singing.'

$$
\begin{aligned}
& \llbracket k e \rrbracket(\mathrm{c})=\lambda \mathrm{i} \lambda \mathrm{p}\left[: \exists \mathrm{i}^{\prime}\left[\mathrm{i}^{\prime} \leq \mathrm{c} \mathrm{p}\left(\mathrm{i}^{\prime}\right)\right] \exists \mathrm{i}^{\prime}\left[\mathrm{i}^{\prime} \leq \mathrm{i} \mathrm{p}\left(\mathrm{i}^{\prime}\right)\right]\right] \\
& \llbracket\left[{ }_{\mathrm{CP}} k e[\mathrm{IP} \text { Enet mo koliet }]\right] \rrbracket(\mathrm{c}) \\
& =\lambda \mathrm{i}[\llbracket k e \rrbracket(\mathrm{c})(\mathrm{i})]([[\text { Ir Enet mo koliet }] \rrbracket(\mathrm{c})(\mathrm{i}))] \\
& =\lambda \mathrm{i}\left[\lambda \mathrm{p}\left[: \exists \mathrm{i}^{\prime}\left[\mathrm{i}^{\prime} \leq \mathrm{c} p\left(\mathrm{i}^{\prime}\right)\right] \exists \mathrm{i}^{\prime}\left[\mathrm{i}^{\prime} \leq \mathrm{i} \wedge \mathrm{p}\left(\mathrm{i}^{\prime}\right)\right]\left(\lambda \mathrm{i}^{\prime}\left[: \exists \mathrm{i}^{\prime}\left[\mathrm{i}^{\prime} \leq \mathrm{c} \varphi\left(\mathrm{i}^{\prime}\right)\right]\left[: \mathrm{i}^{\prime} \leq \mathrm{i} \varphi\left(\mathrm{i}^{\prime}\right)\right]\right]\right)\right]\right.
\end{aligned}
$$

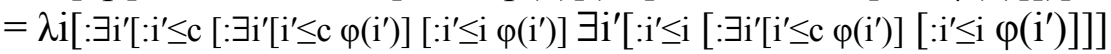

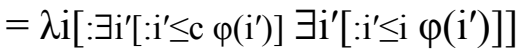

I assume a standard interpretation of kiibele as a propositional attitude verb; it expresses belief in a proposition that is presupposed to be true. To believe a proposition $\Phi$ means that $\Phi$ is true at all indices that are compatible with one's be liefs. We assume a doxastic operator to express belief, (20), and model knowledge with a factive presupposition, (21): 
(20) DOX(x)(i)(i') iff $i^{\prime}$ is compatible with the beliefs that $x$ holds at $i$ about $i$.

(21) kiibele $(\mathrm{c})=\lambda \mathrm{i} \lambda \mathrm{p} \lambda \mathrm{x}\left[\mathrm{:p}(\mathrm{c}) \forall \mathrm{i}^{\prime \prime}: \operatorname{DOX}(\mathrm{x})(\mathrm{i})\left(\mathrm{i}^{\prime \prime}\right) \mathrm{p}\left(\mathrm{i}^{\prime \prime}\right)\right]$

The interpretation of the VP of (17) is computed as in (22). F or the last step in the derivation, notice that $\exists i^{\prime} \leq c\left[\varphi\left(i^{\prime}\right)\right]$ is independent of $i^{\prime \prime}$, hence this presupposition is projected, where it is consonant with the factive presupposition of kiibele.

(22) $\llbracket[$ vp kiibele $[\mathrm{cP}$ ke Enet mo koliet $]] \rrbracket(\mathrm{c})$

$=\lambda \mathrm{i}[\llbracket$ kiibele $\rrbracket(\mathrm{c})(\mathrm{i})(\llbracket[\mathrm{cP}$ ke Enet mo koliet $] \rrbracket(\mathrm{c}))]$

$=\lambda \mathrm{i} \lambda \mathrm{x}\left[:\left[: \exists \mathrm{i}^{\prime}\left[\mathrm{i}^{\prime} \leq \mathrm{c} \varphi\left(\mathrm{i}^{\prime}\right)\right] \exists \mathrm{i}^{\prime}\left[\mathrm{i}^{\prime} \leq \mathrm{c} \varphi\left(\mathrm{i}^{\prime}\right)\right]\right]\right.$ $\left.\forall \mathrm{i}^{\prime \prime}: \operatorname{DOX}(\mathrm{x})(\mathrm{i})\left(\mathrm{i}^{\prime \prime}\right)\left[: \exists \mathrm{i}^{\prime}\left[\mathrm{i}^{\prime} \leq \mathrm{c} \varphi\left(\mathrm{i}^{\prime}\right)\right] \exists \mathrm{i}^{\prime}\left[: \mathrm{i}^{\prime} \leq \mathrm{i}^{\prime \prime} \varphi\left(\mathrm{i}^{\prime}\right)\right]\right]\right]$

$=\lambda \mathrm{i} \lambda x\left[: \exists \mathrm{i}^{\prime}\left[\mathrm{i}^{\prime} \leq \mathrm{c}\left[\varphi\left(\mathrm{i}^{\prime}\right)\right] \forall \mathrm{i}^{\prime \prime}: \operatorname{DOX}(\mathrm{x})(\mathrm{i})\left(\mathrm{i}^{\prime \prime}\right) \exists \mathrm{i}^{\prime}\left[\mathrm{i}^{\prime} \leq \mathrm{i}^{\prime \prime} \varphi\left(\mathrm{i}^{\prime}\right)\right]\right]\right]$, cf. (3c,d, (5a)

In the next steps, the subject, modality and existential closure of the main clause are supplied, cf. (23). When asserted, we get the change of an input com mon ground $\mathrm{C}$ in (24).

(23) $\llbracket\left[{ }_{\mathrm{CP}} \exists\left[\right.\right.$ IP Lising [mwi $\left[\mathrm{vP} \mathrm{t}_{\text {Lising }}\right.$ kiibele ke Enet mo koliet $\left.\left.\left.]\right]\right]\right] \rrbracket$ $=\lambda c \lambda \mathrm{i}\left[: \exists \mathrm{i}^{\prime}\left[\mathrm{i}^{\prime} \leq \mathrm{c}(22)(\operatorname{Lising})\right]\left(\mathrm{i}^{\prime}\right)\right] \exists \mathrm{i}^{\prime}\left[: \mathrm{i}^{\prime} \leq \mathrm{i}(22)(\right.$ Lising $\left.\left.)\left(\mathrm{i}^{\prime}\right)\right]\right]$

(24) $\mathbb{[}\left[{ }_{\text {Forcep }}\right.$ ASSERT [ ${ }_{\mathrm{CP}}$ Lising mwi kiibele ke Enet mo koliet $\left.]\right] \rrbracket(\mathrm{C})$

$=\lambda \mathrm{c}[\mathrm{C}(\mathrm{c}) \wedge !(23)(\mathrm{c})(\mathrm{c})]$

$=\lambda \mathrm{c}\left[\mathrm{C}(\mathrm{c}) \wedge !\left[: \exists \mathrm{i}^{\prime}\left[\mathrm{i}^{\prime} \leq \mathrm{c}(22)(\right.\right.\right.$ Lising $\left.)\left(\mathrm{i}^{\prime}\right)\right] \exists \mathrm{i}^{\prime}\left[\mathrm{i}^{\prime} \leq \mathrm{c}(22)(\right.$ Lising $\left.\left.\left.)\left(\mathrm{i}^{\prime}\right)\right]\right]\right]$

$=\lambda \mathrm{c}\left[\mathrm{C}(\mathrm{c}) \wedge ! \exists \mathrm{i}^{\prime}\left[\mathrm{i}^{\prime} \leq \mathrm{c}(22)(\right.\right.$ Lising $\left.\left.\left.)\left(\mathrm{i}^{\prime}\right)\right]\right]\right]$, cf. $(3 \mathrm{~d}, \mathrm{e})$

$=\lambda \mathrm{c}\left[\mathrm{C}(\mathrm{c}) \wedge ! \exists \mathrm{i}^{\prime}\left[\mathrm{i}^{\prime} \leq \mathrm{c}: \exists \mathrm{i}^{\prime} \leq \mathrm{c}\left[\varphi\left(\mathrm{i}^{\prime}\right)\right] \forall \mathrm{i}^{\prime \prime}: \operatorname{DOX}(\operatorname{Lising})\left(\mathrm{i}^{\prime}\right)\left(\mathrm{i}^{\prime \prime}\right) \exists \mathrm{i}^{\prime}\left[\mathrm{i}^{\prime} \leq \mathrm{i}^{\prime \prime} \varphi\left(\mathrm{i}^{\prime}\right)\right]\right]\right]$

$=\lambda \mathrm{c}\left[\mathrm{C}(\mathrm{c}) \wedge !\left[: \exists \mathrm{i}^{\prime} \leq \mathrm{c}\left[\varphi\left(\mathrm{i}^{\prime}\right)\right] \exists \mathrm{i}^{\prime}\left[\mathrm{i}^{\prime} \leq \mathrm{c} \forall \mathrm{i}^{\prime \prime}: \operatorname{DOX}(\right.\right.\right.$ Lising $\left.\left.)\left(\mathrm{i}^{\prime}\right)\left(\mathrm{i}^{\prime \prime}\right) \exists \mathrm{i}^{\prime}\left[: \mathrm{i}^{\prime} \leq \mathrm{i}^{\prime \prime} \varphi\left(\mathrm{i}^{\prime}\right)\right]\right]\right]$

$=\lambda \mathrm{c}\left[\mathrm{C}(\mathrm{c}) \wedge \exists \mathrm{i}^{\prime} \leq \mathrm{c}\left[\varphi\left(\mathrm{i}^{\prime}\right)\right] \wedge \exists \mathrm{i}^{\prime} \leq \mathrm{c} \forall \mathrm{i}^{\prime \prime}: \operatorname{DOX}(\right.$ Lising $\left.)\left(\mathrm{i}^{\prime}\right)\left(\mathrm{i}^{\prime \prime}\right) \exists \mathrm{i}^{\prime} \leq \mathrm{i}^{\prime \prime}\left[\varphi\left(\mathrm{i}^{\prime}\right)\right]\right]$

The realis presupposition $: \exists \mathrm{i}^{\prime}\left[\mathrm{i}^{\prime} \leq \mathrm{c} \varphi\left(\mathrm{i}^{\prime}\right)\right]$ of the embedded clause is projected, following (3b). The output common ground (24) is such that at or before each c, Enet sang; this captures the factivity of the embedded clause. In addition, at an index $i^{\prime}$ at or before $c$, the doxastically accessible worlds $i^{\prime \prime}$ for Lising at $i^{\prime}$ (the in dices compatible with Lising's knowledge at $i^{\prime}$ about $i^{\prime}$ ) are such that Enet sings at or before $i^{\prime \prime}$. Hence the assertion of (23) adds the information that Enet sings at or before c, and that it is compatible with Lising's beliefs at or before c that Enet sings at or before any index $i^{\prime \prime}$ that Lising might take to be the context.

The realis presupposition is also justified in reason and temporal clauses that refer to past situations, cf. (10). (11). The reason clause (25), meaning 'Enet is singing/sang because Lising is dancing / danced', is interpreted as in (26).

[IP [IP Enet mo koliet] [AdvP byen ke Lising mwe sap]] 
Realis and non-realis modality

a. $\left.\llbracket b y e n \rrbracket(\mathrm{c})=\lambda \mathrm{i} \lambda \mathrm{i}^{\prime} \lambda \mathrm{p} \lambda \mathrm{r}\left[\mathrm{r}(\mathrm{i})\left(\mathrm{i}^{\prime}\right) \wedge \mathrm{p}(\mathrm{i}) \wedge \forall \mathrm{i}^{\prime \prime} \mathrm{R}(\mathrm{c})\left(\mathrm{i}^{\prime \prime}\right)\left[\neg \mathrm{q}\left(\mathrm{i}^{\prime \prime}\right) \rightarrow \neg \exists \mathrm{i}^{\prime} \mathrm{r}\left(\mathrm{i}^{\prime \prime}\right)\left(\mathrm{i}^{\prime}\right)\right]\right]\right]$

b. $\mathbb{[}[\mathrm{cP}$ ke Lising mwe sap $] \rrbracket(\mathrm{c})=\lambda \mathrm{i}\left[: \exists \mathrm{i}^{\prime}\left[\mathrm{i}^{\prime} \leq \mathrm{c} \psi\left(\mathrm{i}^{\prime}\right)\right] \exists \mathrm{i}^{\prime}\left[: \mathrm{i}^{\prime} \leq \mathrm{i} \psi\left(\mathrm{i}^{\prime}\right)\right]\right]$

c. $\mathbb{[}\left[{ }_{\mathrm{Adv}}\right.$ byen $[\mathrm{cP}$ ke Lising mwe sap $\left.]\right] \rrbracket(\mathrm{c})$

$=\lambda \mathrm{i} \lambda \mathrm{i}^{\prime}\left[\llbracket\right.$ byen $\rrbracket(\mathrm{c})(\mathrm{i})\left(\mathrm{i}^{\prime}\right)(\llbracket[\mathrm{CP}$ ke Lising mwe sap $\left.] \rrbracket(\mathrm{c}))\right]$

$=\lambda \mathrm{i} \lambda \mathrm{i}^{\prime} \lambda \mathrm{r}\left[: \exists \mathrm{i}^{\prime}\left[\mathrm{i}^{\prime} \leq \mathrm{c} \psi\left(\mathrm{i}^{\prime}\right)\right]\left[\mathrm{r}(\mathrm{i})\left(\mathrm{i}^{\prime}\right) \wedge \exists \mathrm{i}^{\prime}\left[\mathrm{i}^{\prime} \leq \mathrm{i} \psi\left(\mathrm{i}^{\prime}\right)\right]\right.\right.$

$\left.\left.\wedge \forall \mathrm{i}^{\prime \prime} \mathrm{R}(\mathrm{c})\left(\mathrm{i}^{\prime \prime}\right)\left[\neg \exists \mathrm{i}^{\prime}\left[: \mathrm{i}^{\prime} \leq \mathrm{i}^{\prime \prime} \psi\left(\mathrm{i}^{\prime \prime}\right)\right] \rightarrow \neg \exists \mathrm{i}^{\prime} \mathrm{r}\left(\mathrm{i}^{\prime \prime}\right)\left(\mathrm{i}^{\prime}\right)\right]\right]\right]$

d. [[IP [IP Enet mo koliet] [AdvP byen ke Lising mwe sap $]] \rrbracket(\mathrm{c})$

$=\lambda \mathrm{i} \lambda \mathrm{i}^{\prime}\left[\llbracket\left[\right.\right.$ Advp byen ke Lising mwe sap $\rrbracket(\mathrm{c})(\mathrm{i})\left(\mathrm{i}^{\prime}\right)(\mathbb{[}[$ IP Enet mo koliet $\left.] \rrbracket(\mathrm{c}))\right]$

$=\lambda \mathrm{i} \lambda \mathrm{i}^{\prime}\left[: \exists \mathrm{i}^{\prime} \leq \mathrm{c}\left[\psi\left(\mathrm{i}^{\prime}\right): \exists \mathrm{i}^{\prime} \leq \mathrm{c}\left[\varphi\left(\mathrm{i}^{\prime}\right)\right]\left[: \mathrm{i}^{\prime} \leq \mathrm{i} \varphi\left(\mathrm{i}^{\prime}\right)\right] \wedge \exists \mathrm{i}^{\prime}\left[\mathrm{i}^{\prime} \leq \mathrm{i} \psi\left(\mathrm{i}^{\prime}\right)\right]\right.\right.$

$\left.\wedge \forall \mathrm{i}^{\prime \prime} \mathrm{R}(\mathrm{c})\left(\mathrm{i}^{\prime \prime}\right)\left[\neg \exists \mathrm{i}^{\prime}\left[: \mathrm{i}^{\prime} \leq \mathrm{i}^{\prime \prime} \psi\left(\mathrm{i}^{\prime \prime}\right)\right] \rightarrow \neg \exists \mathrm{i}^{\prime}\left[: \mathrm{i}^{\prime} \leq \mathrm{i}^{\prime \prime} \varphi\left(\mathrm{i}^{\prime}\right)\right]\right]\right]$

The causal relation states that for all indices $i^{\prime \prime}$ in the accessibility relation $R$, if there were no index $i^{\prime}$ before $i^{\prime \prime}$ at which Lising dances, there would not be an index $i^{\prime}$ before $i^{\prime \prime}$ at which Enet sings. The negation leaves the presuppositions of the two subclauses untouched, cf. (3a); they project, being are independent of i", and become presuppositions of the whole sentence, following (3b).

\section{Realis Negation -re / tere}

We have seen that realis creates a presupposition that its host proposition is true at the context index c or some index before c. Hence realis clauses cannot be negated, as this would result in a proposition that is undefined at every index; asserting this proposition would reduce the common ground $\mathrm{C}$ to the empty set. So, how is negation expressed? Narrow-scope negation over vP with subsequent realis marking and existential closure leads to $\lambda \mathrm{i}\left[: \exists \mathrm{i}^{\prime} \leq \mathrm{c}\left[\neg \varphi\left(\mathrm{i}^{\prime}\right)\right] \exists \mathrm{i}^{\prime} \leq \mathrm{i}\left[\neg \varphi\left(\mathrm{i}^{\prime}\right)\right]\right]-$ not what we want, because this just states that the host proposition $\varphi$ was false at some index before the reference/context index $i$. Rather, negation is expressed by a separate modal operator in place of the realis operator, cf. example (9) and (27), a sentence about former warfare between two villages that are now closely allied. Realis negation also occurs in embedded clauses in factive contexts, i.e. in cases in which it is presupposed that the host proposition is false, as in (28).

$\begin{array}{llll}\text { Lalinda mane Langievot kolo-re } & \text { wu wuo mane koloo } \\ \text { Lalinda with Langievot } & \text { 3DU-RENEG good.REDUP } & \text { with } 3 \mathrm{DU}\end{array}$

'Lalinda and Langievot weren't on good terms with each other' (Andri.005)

(28) Taata a-bwe kiibele ke ngyo na-re Isao

Father FUT-POT know CP.RE 1SG 1SG-RENEG Esau

'Father will know that I am not Esau', translation (OT.353)

This suggests that realis negation negates its host proposition and presupposes that the host proposition is false at the context index. This will be illustrated with example (29), which is interpreted as first approximation as in (30). 
[Forcep ASSERT [ ${ }_{\mathrm{CP}} \exists\left[{ }_{\mathrm{IP}}\right.$ Enet $\left[\mathrm{I}_{\mathrm{I}^{\prime}}\left[\mathrm{I}^{\circ}\right.\right.$ tere $]\left[{ }_{\mathrm{vP}} \mathrm{t}_{\text {Enet }}\right.$ koliet $\left.\left.\left.\left.]\right]\right]\right]\right]$

'Enet does not sing.', 'Enet did not sing'

$$
\begin{aligned}
& \text { a. } \llbracket-r e \rrbracket(c)=\lambda i \lambda \mathrm{i}^{\prime} \lambda \mathrm{p}\left[: \neg \exists \mathrm{i}^{\prime}\left[\mathrm{i}^{\prime} \leq \mathrm{c} p\left(\mathrm{i}^{\prime}\right)\right]\left[: \mathrm{i}^{\prime} \leq \mathrm{i} \neg \mathrm{p}\left(\mathrm{i}^{\prime}\right)\right]\right] \\
& \text { b. } \left.\mathbb{[}\left[\mathrm{IP} \text { Enet }\left[\mathrm{II}_{\mathrm{I}^{\circ}} \mathrm{I}^{\circ} \text { tere }\right]\left[{ }_{\mathrm{vP}} \mathrm{t}_{\text {Enet }} \text { koliet }\right]\right]\right] \rrbracket(\mathrm{c}) \\
& =\lambda \mathrm{i} \lambda \mathrm{i}^{\prime}\left[\llbracket-r e \rrbracket(\mathrm{c})(\mathrm{i})\left(\mathrm{i}^{\prime}\right)\left(\mathbb{\llbracket}\left[\text { vp }_{\text {Enet }} \text { koliet }\right] \rrbracket(\mathrm{c})(\mathrm{i})\right)\right. \\
& =\lambda \mathrm{i} \lambda \mathrm{i}^{\prime}\left[: \neg \exists \mathrm{i}^{\prime}\left[\mathrm{i}^{\prime} \leq \mathrm{c} \varphi\left(\mathrm{i}^{\prime}\right)\right]\left[: \mathrm{i}^{\prime} \leq \mathrm{i} \neg \varphi\left(\mathrm{i}^{\prime}\right)\right]\right] \\
& \text { c. } \left.\mathbb{[}\left[\mathrm{CP} \exists\left[{ }_{\text {IP }} \text { Enet }\left[\text { I }^{\prime}\left[\mathrm{I}^{\circ} \text { tere }\right]\left[{ }_{\mathrm{vP}} \mathrm{t}_{\text {Enet }} \text { koliet }\right]\right]\right]\right]\right](\mathrm{c}) \\
& =\lambda \mathrm{i}\left[\llbracket \exists \rrbracket(\mathrm{c})\left(\llbracket\left[\mathrm{IIP}_{\text {Enet }}\left[\mathrm{I}^{\prime}\left[\mathrm{I}^{\circ} \text { tere }\right]\left[\mathrm{vp}_{\mathrm{E}_{\text {Enet }}} \text { koliet }\right]\right]\right] \rrbracket(\mathrm{c})(\mathrm{i})\right)\right] \\
& =\lambda \mathrm{i}\left[: \neg \exists \mathrm{i}^{\prime}\left[\mathrm{i}^{\prime} \leq \mathrm{c} \varphi\left(\mathrm{i}^{\prime}\right)\right] \exists \mathrm{i}^{\prime}\left[: \mathrm{i}^{\prime} \leq \mathrm{i} \neg \varphi\left(\mathrm{i}^{\prime}\right)\right]\right] \\
& \text { d. 【ASSERT } \rrbracket(C)\left(\llbracket\left[\text { IP Enet tere } \mathrm{t}_{\text {Enet }} \text { koliet }\right] \rrbracket\right) \\
& =\lambda \mathrm{c}\left[\mathrm{C}(\mathrm{c}) \wedge !\left[: \neg \exists \mathrm{i}^{\prime}\left[\mathrm{i}^{\prime} \leq \mathrm{c} \varphi\left(\mathrm{i}^{\prime}\right)\right] \exists \mathrm{i}^{\prime}\left[\mathrm{i}^{\prime} \leq \mathrm{c} \neg \varphi(\mathrm{i})\right]\right]\right. \\
& =\lambda \mathrm{c}\left[\mathrm{C}(\mathrm{c}) \wedge \neg \exists \mathrm{i}^{\prime} \leq \mathrm{c}[\varphi(\mathrm{i})]\right], \mathrm{cf} .(3)(\mathrm{e})
\end{aligned}
$$

Realis negation expresses an antifactive presupposition and negates the host proposition, cf. $(30 \mathrm{a}, \mathrm{b})$. Existential closure at the $\mathrm{CP}$ level then states that there is an index $i^{\prime}$ at or before $i$ such that the host proposition is false, cf. (30c). After as sertion, cf. (30d), i is identified with c, and this existential claim becomes trivial under the antifactive presupposition. The presupposition is turned to a regular meaning due to !, and the common ground $\mathrm{C}$ is restricted to those indices c for which it holds that there is no preceding or equal index $i^{\prime}$ at which Enet sings.

The analysis of realis negation has to be refined in one important aspect. For (27) it would imply that the two villages are still at war with each other at the context index, which is not the case. The range for which non-existence of an index is claimed has to be pragmatically restricted; cf. Partee 1973 for examples like $I$ didn't turn off the stove. We can assume that the context provides a reference interval, a history $\mathrm{h}$ before or reaching up to $\mathrm{c}$, as a parameter. Realis and realis negation then could be interpreted as follows:

(31) a. $\llbracket\left[\mathrm{I}^{\circ}-m\right] \rrbracket(\mathrm{c})=\lambda \mathrm{i} \lambda \mathrm{i}^{\prime} \lambda \mathrm{p}\left[: \mathrm{h} \leq \mathrm{c}: \exists \mathrm{i}^{\prime} \in \mathrm{h}\left[\mathrm{p}\left(\mathrm{i}^{\prime}\right)\right]\left[: \mathrm{h} \leq \mathrm{i}: \mathrm{i}^{\prime} \in \mathrm{h} \mathrm{p}(\mathrm{i})\right]\right]$

b. $\llbracket-r e \rrbracket(c)=\lambda i \lambda i^{\prime} \lambda p\left[: h \leq c: \neg \exists i^{\prime} \in h\left[p\left(i^{\prime}\right)\right]\left[: h \leq i: i^{\prime} \in h \neg p\left(i^{\prime}\right)\right]\right]$

Recall that histories are intervals of indices, cf. (1b); $h \leq c$ holds if for all $i \in h$, $\mathrm{i} \leq \mathrm{c}$. Referring to histories in this way does not change the truth conditions for realis-marked propositions, but affects propositions marked by realis negation.

\section{Potentialis $-p / b(w) V$}

Potentialis modality is used in main clauses to express directive, cf. (32), hortative, cf. (33), or commissive speech acts, cf. (34). 
Realis and non-realis modality

(32) ko-p sengane de-re $e^{3}$ na-p ane.

2SG-POT give.TR NRE-PART 1SG-POT eat.TR

'Give me some of it so I can eat it.' (Boa2.076)

(33) ngaledo-p bá meleh byen soló.

then 1+2.DU-POT plant food because wedding.feast

'After that, let's plant food for the wedding.' (Aiben7.009)

(34) na-p sengane suburu manes-ok tuutuu man

1SG-POT give.TR mat to CL1-1SG grandparent male

'I promise to give the mat to my grandfather' (Aiben7.023)

These cases have in common that they refer to events that can be realized in the future. They share this property with predictions about what will happen in the future. However, such predictions are marked by a prefix $a$ - on a potentialis subject marker, as seen in (21) and (35). Note that (35) does not express a promise, but a prediction, as it is part of a monologue of the speaker.

$$
\begin{aligned}
& \text { li=malek a-na-p kuo a-na-p tinyam. } \\
& \text { at=night FUT-1SG-POT run FUT-1SG-POT hide } \\
& \text { 'At night, I will run and hide.' personal story, (Abel3.079) }
\end{aligned}
$$

In embedded clauses, potentialis occurs in non-factive environments in which the host proposition may become true, e.g. the expression of wishes, cf. (36), and abilities, cf. (37). Potentialis clauses use the complementizer $k a$, like other non-realis clauses. Notice that kiibele 'to know', which expresses a factive epistemic notion in (9) and (17), also marks ability, similar to English to know that vs. to know how. Irrealis clauses also occur in non-factive adjunct clauses, cf. (38).

$$
\begin{array}{lllll}
\text { na-m longbini } & \boldsymbol{k} \boldsymbol{a} & \text { na-p pune pun-en } & \text { soo } \\
\text { 1S-RE want } & \text { CP.NR } & \text { 1SG-POT tell } & \text { tell-NOMIN } & \text { IDEF } \\
\text { 'I want to tell a story' (Andri2.002) } &
\end{array}
$$

$$
\text { ngale la-m kiibele } k a \text { la-p kuo soo } \sim \text { soo }
$$$$
\text { then 3PL-RE able CP.NR 3PL-POT run one-REDUP }
$$

'Then they were able to run away one by one.' (Adam1.022)

$$
\begin{aligned}
& \text { a-na-p ane sówe bili ka ot bi mitmyet? } \\
& \text { FUT-1SG-POT eat.TR what time CP.NR place POT dark } \\
& \text { 'What will I eat when it is dark?' (JoeAlvi.028) }
\end{aligned}
$$

I propose to model potentialis as expressing that the host proposition is true at some later index, and as presupposing the same, cf. (39). Consequently, poten-

3 In non-realis contexts, indefinites are marked by the prefix de-, expressing scopal dependence on non-realis operators, and hence lack of existential import. Cf. also examples (55), (57). 
tialis presupposes that the host proposition can be realized, and that it cannot be negated. Just as with realis, it needs a special type of negation, see Section 6 .
a. $\llbracket b o \rrbracket(c)=\lambda i \lambda i^{\prime} \lambda p\left[: \exists i^{\prime}\left[: i<i^{\prime} p\left(i^{\prime}\right)\right]\left[: i<i^{\prime} p\left(i^{\prime}\right)\right]\right]$
b. $\mathbb{U}\left[\right.$ IP Enet $\left[\mathrm{I}^{\prime}\right.$ bo $\left[\mathrm{vP} \mathrm{t}_{\text {Enet }}\right.$ koliet $\left.\left.]\right]\right] \rrbracket(\mathrm{c})=\lambda \mathrm{i} \lambda \mathrm{i}^{\prime}\left[: \exists \mathrm{i}^{\prime}\left[\mathrm{i}<\mathrm{i}^{\prime} \varphi\left(\mathrm{i}^{\prime}\right)\right]\left[: \mathrm{i}<\mathrm{i}^{\prime} \varphi\left(\mathrm{i}^{\prime}\right)\right]\right]$

An existentially closed CP based on a potentialis IP cannot be asserted. We would get the meaning (40), which restricts the common ground $\mathrm{C}$ to those indices that are followed by some index for which the host proposition is true. This is too weak to be informative; it just states that $\varphi$ can become true in principle.

$$
\begin{aligned}
& \llbracket[\text { ForceP ASSERT [CP } \exists[\text { IP Enet bo koliet }]]] \rrbracket(\mathrm{C}) \\
& =\lambda \mathrm{c}\left[\mathrm{C}(\mathrm{c}) \wedge !\left[: \exists \mathrm{i}^{\prime}\left[: \mathrm{c}<\mathrm{i}^{\prime} \varphi\left(\mathrm{i}^{\prime}\right)\right] \exists \mathrm{i}^{\prime}\left[: \mathrm{c}<\mathrm{i}^{\prime} \varphi\left(\mathrm{i}^{\prime}\right)\right]\right]\right. \\
& =\lambda \mathrm{c}\left[\mathrm{C}(\mathrm{c}) \wedge \exists \mathrm{i}^{\prime}\left[\mathrm{c}<\mathrm{i}^{\prime} \wedge \varphi\left(\mathrm{i}^{\prime}\right)\right]\right], \text { cf. }(3 \mathrm{~d}, \mathrm{e}, \mathrm{f})
\end{aligned}
$$

Potentialis clauses can be used to express predictions in combination with the prefix $a$-, cf. (35), (38). This prefix is derived from the nonrealis complementizer $k a$, which is used in Daakaka. This justifies an analysis of $a$ - as CP head, cf. (41).

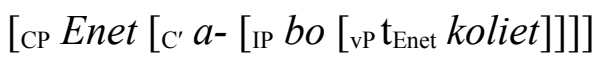

The prefix $a$ - expresses a quantification over histories starting after an index i that are deemed to be possible developments that the world might take, cf. Dowty (1977). I assume for $a$ - an accessibility relation FUT, cf. (42), where FUT(i)(h) stands for: $\mathrm{h}$ is a history with $\mathrm{i}<\mathrm{h}$ that is a plausible future at $\mathrm{i}$, i.e. $\mathrm{h}$ does not contain developments that run against expectations in $\mathrm{i}$. We then get the interpretation (43), where we use the functional notation, e.g. $h\left(i^{\prime}\right)$ stands for $i^{\prime} \in h$.

$$
\begin{aligned}
& \llbracket a-\rrbracket(\mathrm{c})=\lambda \mathrm{i} \lambda \mathrm{p} \forall \mathrm{h}: \operatorname{FUT}(\mathrm{i})(\mathrm{h}) \exists \mathrm{i}^{\prime}: \mathrm{h}\left(\mathrm{i}^{\prime}\right) \mathrm{p}\left(\mathrm{i}^{\prime}\right) \\
& \text { a. } \left.\mathbb{[}\left[{ }_{\mathrm{CP}} \text { Enet }\left[_{\mathrm{C}^{\prime}} a-\left[{ }_{\mathrm{IP}} b o\left[{ }_{\mathrm{vP}} \mathrm{t}_{\mathrm{Enet}} \text { koliet }\right]\right]\right]\right]\right](\mathrm{c}) \\
& =\lambda \mathrm{i}\left[\llbracket a-\rrbracket(\mathrm{c})(\mathrm{i})\left(\llbracket\left[\text { IP } b o\left[{ }_{\mathrm{vP}} \text { Enet koliet }\right]\right] \rrbracket(\mathrm{c})(\mathrm{i})\right)\right] \\
& =\lambda \mathrm{i} \forall \mathrm{h}: \text { FUT(i)(h) } \exists \mathrm{i}^{\prime}: \mathrm{h}\left(\mathrm{i}^{\prime}\right)\left[: \exists \mathrm{i}^{\prime}\left[: \mathrm{i}^{<} \mathrm{i}^{\prime} \varphi\left(\mathrm{i}^{\prime}\right)\right]\left[: \mathrm{i}<\mathrm{i}^{\prime} \varphi\left(\mathrm{i}^{\prime}\right)\right]\right] \\
& =\lambda \mathrm{i}\left[: \exists \mathrm{i}^{\prime}\left[\mathrm{i}<\mathrm{i}^{\prime} \varphi\left(\mathrm{i}^{\prime}\right)\right] \forall \mathrm{h}: \text { FUT(i)(h) } \exists \mathrm{i}^{\prime}: \mathrm{h}\left(\mathrm{i}^{\prime}\right)\left[: \mathrm{i}<\mathrm{i}^{\prime} \varphi\left(\mathrm{i}^{\prime}\right)\right]\right] \\
& =\lambda \mathrm{i}\left[: \exists \mathrm{i}^{\prime}\left[\mathrm{i}<\mathrm{i}^{\prime} \varphi\left(\mathrm{i}^{\prime}\right)\right] \forall \mathrm{h}: \mathrm{FUT}(\mathrm{i})(\mathrm{h}) \exists \mathrm{i}^{\prime}: \mathrm{h}\left(\mathrm{i}^{\prime}\right) \varphi\left(\mathrm{i}^{\prime}\right)\right] \text {, as FUT(i)(h) entails } \mathrm{i}<\mathrm{h} \\
& \text { b. } \left.\mathbb{[}\left[\text { Forcep ASSERT [ }{ }_{\mathrm{CP}} \text { Enet abo koliet }\right]\right] \rrbracket(\mathrm{C}) \\
& =\lambda \mathrm{c}\left[\mathrm{C}(\mathrm{c}) \wedge !\left[: \exists \mathrm{i}^{\prime}\left[\mathrm{c}<\mathrm{i}^{\prime} \varphi\left(\mathrm{i}^{\prime}\right)\right] \forall \mathrm{h}: \mathrm{FUT}(\mathrm{c})(\mathrm{h}) \exists \mathrm{i}^{\prime}: \mathrm{h}\left(\mathrm{i}^{\prime}\right) \varphi\left(\mathrm{i}^{\prime}\right)\right]\right] \\
& \left.=\lambda \mathrm{c}\left[\mathrm{C}(\mathrm{c}) \wedge \exists \mathrm{i}^{\prime}\left[\mathrm{c}<\mathrm{i}^{\prime} \wedge \varphi\left(\mathrm{i}^{\prime}\right)\right] \wedge \forall \mathrm{h}: \operatorname{FUT}(\mathrm{c})(\mathrm{h}) \exists \mathrm{i}^{\prime}: \mathrm{h}\left(\mathrm{i}^{\prime}\right) \varphi\left(\mathrm{i}^{\prime}\right)\right]\right]
\end{aligned}
$$

The future potentials proposition (43a) applies to indices $i$ for which it holds that all plausible future histories after i contain an index at which the host proposition - that Enet sings - is true. The potentialis presupposition that there is such a future index projects, and is entailed by the non-presupposed part under the trivial assumptions that there are future histories with respect to i. When asserted, cf. (43b), this restricts the common ground $\mathrm{C}$ to indices $\mathrm{c}$ for which all future histo - 
ries relative to $\mathrm{c}$ make the host proposition true at some index or other. Notice that from this representation we can derive that $a$ - cannot combine with realis modality, as in *Enet a-mo koliet, as FUT(c)(h) implies $\mathrm{c}<\mathrm{h}$, which is not compatible with the realis requirement that the host proposition is true at an index $i^{\prime}, i^{\prime} \leq \mathrm{c}$. Fol lowing Gajewski (2002), such structural contradictions result in ungrammaticality.

Directives, hortatives and commissives are analyzed are non-assertive speech acts in which the speaker expresses a preference of certain histories over others. We can model this by assuming a ForceP with an operator PREF:

\section{[ForceP PREF [ip Enet bo koliet]]}

We can assume that a context comes with a preference set, $\operatorname{PREF}(\mathrm{c})$, a property of histories that follow c and that are preferred as continuations of c. Preference clauses restrict the preferred propositions, taking an IP, a propositional relation, not a $\mathrm{CP}$, a proposition.

$$
\begin{aligned}
& \llbracket P R E F \rrbracket(C)=\lambda \mathrm{s} \lambda \mathrm{c}\left[\mathrm{C}(\mathrm{c}) \wedge ! \forall \mathrm{h}: \operatorname{PREF}(\mathrm{c})(\mathrm{h}) \exists \mathrm{i}^{\prime}: \mathrm{h}\left(\mathrm{i}^{\prime}\right) \mathrm{s}(\mathrm{c})(\mathrm{c})\left(\mathrm{i}^{\prime}\right)\right] \\
& \mathbb{\llbracket}[\text { ForceP PREF [IP Enet bo koliet }]]] \rrbracket(\mathrm{C}) \\
& =\lambda \mathrm{s} \lambda \mathrm{c}\left[\mathrm{C}(\mathrm{c}) \wedge \forall \mathrm{h}: \operatorname{PREF}(\mathrm{c})(\mathrm{h}) \exists \mathrm{i}^{\prime}: \mathrm{h}\left(\mathrm{i}^{\prime}\right) \mathrm{s}(\mathrm{c})(\mathrm{c})\left(\mathrm{i}^{\prime}\right)\right](\mathbb{L}[\text { IP Enet bo koliet }] \rrbracket) \\
& =\lambda \mathrm{c}\left[\mathrm{C}(\mathrm{c}) \wedge ! \forall \mathrm{h}: \operatorname{PREF}(\mathrm{c})(\mathrm{h}) \exists \mathrm{i}^{\prime}: \mathrm{h}\left(\mathrm{i}^{\prime}\right) \llbracket\left[[\mathrm{IP} \text { Enet bo koliet }](\mathrm{c})(\mathrm{c})\left(\mathrm{i}^{\prime}\right)\right]\right. \\
& =\lambda \mathrm{c}\left[\mathrm{C}(\mathrm{c}) \wedge ! \forall \mathrm{h}: \operatorname{PREF}(\mathrm{c})(\mathrm{h}) \exists \mathrm{i}^{\prime}: \mathrm{h}\left(\mathrm{i}^{\prime}\right)\left[: \exists \mathrm{i}^{\prime}\left[\mathrm{c}<\mathrm{i}^{\prime} \varphi\left(\mathrm{i}^{\prime}\right)\right]\left[: \mathrm{c}<\mathrm{i}^{\prime} \varphi\left(\mathrm{i}^{\prime}\right)\right]\right]\right. \\
& =\lambda \mathrm{c}\left[\mathrm{C}(\mathrm{c}) \wedge !\left[: \exists \mathrm{i}^{\prime}\left[\mathrm{c}<\mathrm{i}^{\prime} \varphi\left(\mathrm{i}^{\prime}\right)\right] \forall \mathrm{h}: \operatorname{PREF}(\mathrm{c})(\mathrm{h}) \exists \mathrm{i}^{\prime}: \mathrm{h}\left(\mathrm{i}^{\prime}\right) \varphi\left(\mathrm{i}^{\prime}\right)\right]\right] \\
& =\lambda \mathrm{c}\left[\mathrm{C}(\mathrm{c}) \wedge \exists \mathrm{i}^{\prime}\left[\mathrm{c}<\mathrm{i}^{\prime} \wedge \varphi\left(\mathrm{i}^{\prime}\right)\right] \wedge \forall \mathrm{h}: \operatorname{PREF}(\mathrm{c})(\mathrm{h}) \exists \mathrm{i}^{\prime}: \mathrm{h}\left(\mathrm{i}^{\prime}\right) \varphi\left(\mathrm{i}^{\prime}\right)\right]
\end{aligned}
$$

This restricts the preferred futures of c to those for which it holds that $\varphi$ becomes true at some index, with the presupposition that $\varphi$ actually may become true at some index after c. This is a plausible interpretation of preferences, which come with a condition of realizability - otherwise, distal or potentialis negation would be used, see Sections 6 and 7 below.

I now turn to the use of potentialis in embedded clauses, which will be discussed with example (47); note the non-realis complementizer $k a$.

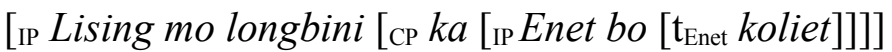

'Lising wants that Enet sings.'

I assume that the irrealis complementizer $k a$ itself expresses a modal notion with an accessibility relation $\mathrm{R}$ that, just like the cognate future marker $a$-and the preference operator PREF, identifies a set of histories, as illustrated in (48).

a. $\llbracket k a \rrbracket(\mathrm{c})=\lambda \mathrm{i} \lambda \mathrm{p} \lambda \mathrm{R} \forall \mathrm{h}: \mathrm{R}(\mathrm{i})(\mathrm{h}) \exists \mathrm{i}^{\prime}: \mathrm{h}\left(\mathrm{i}^{\prime}\right) \mathrm{p}\left(\mathrm{i}^{\prime}\right)$

b. $\mathbb{[}\left[\mathrm{CP} k a\right.$ [IP Enet bo t $_{\text {Enet }}$ koliet $\left.]\right] \rrbracket(\mathrm{c})$

$=\lambda \mathrm{i}\left[\llbracket k a \rrbracket(\mathrm{c})(\mathrm{i})\left(\llbracket\left[\right.\right.\right.$ IP Enet bo $\mathrm{t}_{\text {Enet }}$ koliet $\left.\left.] \rrbracket(\mathrm{c})(\mathrm{i})\right)\right]$

$=\lambda \mathrm{i} \lambda \mathrm{R} \forall \mathrm{h}: \mathrm{R}(\mathrm{i})(\mathrm{h}) \exists \mathrm{i}^{\prime}: \mathrm{h}\left(\mathrm{i}^{\prime}\right)$ ! [: $\left.\exists \mathrm{i}^{\prime}\left[: \mathrm{i}^{\prime} \mathrm{i}^{\prime} \varphi\left(\mathrm{i}^{\prime}\right)\right]\left[: \mathrm{i}<\mathrm{i}^{\prime} \varphi\left(\mathrm{i}^{\prime}\right)\right]\right]$

$=\lambda \mathrm{i} \lambda \mathrm{R}\left[: \exists \mathrm{i}^{\prime}\left[\mathrm{i}<\mathrm{i}^{\prime} \varphi\left(\mathrm{i}^{\prime}\right)\right] \forall \mathrm{h}: \mathrm{R}(\mathrm{i})(\mathrm{h}) \exists \mathrm{i}^{\prime}: \mathrm{h}\left(\mathrm{i}^{\prime}\right) \varphi\left(\mathrm{i}^{\prime}\right)\right]$ 
The accessibility relation $\mathrm{R}$ gets specified by the embedding verb longbini 'want', expressing buletic modality. This is rendered by the relation PREF(x), where $\operatorname{PREF}(\mathrm{x})(\mathrm{i})(\mathrm{h})$ holds if $\mathrm{h}$ is a history after $\mathrm{i}$ that is preferred by person $\mathrm{x}$ at $\mathrm{i}$ :

a. $\llbracket$ longbini $\rrbracket(\mathrm{c})=\lambda \mathrm{i} \lambda \mathcal{R} \lambda \mathrm{x}[\mathcal{R}(\operatorname{PREF}(\mathrm{x}))(\mathrm{i})]$

b. $\llbracket\left[\right.$ longbini $\left[\right.$ ст ka Enet bo t $_{\text {Enet }}$ koliet $\left.]\right] \rrbracket(\mathrm{c})$ $=\lambda \mathrm{i}\left[\llbracket\right.$ longbini $\rrbracket(\mathrm{c})(\mathrm{i})\left(\llbracket\left[\right.\right.$ cP $k a$ Enet bo $\mathrm{t}_{\text {Enet }}$ koliet $\left.\left.] \rrbracket(\mathrm{c})(\mathrm{i})\right)\right]$

$=\lambda \mathrm{i} \lambda \mathrm{x}\left[: \exists \mathrm{i}^{\prime}\left[: \mathrm{i}^{\mathrm{i}} \mathrm{i}^{\prime} \varphi\left(\mathrm{i}^{\prime}\right)\right] \forall \mathrm{h}: \operatorname{PREF}(\mathrm{x})(\mathrm{i})(\mathrm{h}) \exists \mathrm{i}^{\prime}: \mathrm{h}\left(\mathrm{i}^{\prime}\right) \varphi\left(\mathrm{i}^{\prime}\right)\right]$

c. $\mathbb{[}\left[\right.$ vp Lising [ longbini ka bo $\mathrm{t}_{\text {Enet }}$ koliet $\left.]\right] \rrbracket(\mathrm{c})$

$$
=\lambda \mathrm{i}\left[: \exists \mathrm{i}^{\prime}\left[\mathrm{i}<\mathrm{i}^{\prime} \varphi\left(\mathrm{i}^{\prime}\right)\right] \forall \mathrm{h}: \operatorname{PREF}(\operatorname{Lising})(\mathrm{i})(\mathrm{h}) \exists \mathrm{i}^{\prime}: \mathrm{h}\left(\mathrm{i}^{\prime}\right) \varphi\left(\mathrm{i}^{\prime}\right)\right]
$$

This vP can be turned into a realis proposition, and asserted, resulting in (50):

$$
\begin{aligned}
& \mathbb{I}[\text { ForceP ASSERT }[\text { сP } \exists[\text { IP Lising mo longbini ka Enet bo koliet }]]] \rrbracket(\mathrm{C}) \\
& \left.=\lambda \mathrm{c}\left[\mathrm{C}(\mathrm{c}) \wedge \exists \mathrm{i}\left[\mathrm{i} \leq \mathrm{c} \wedge \exists \mathrm{i}^{\prime}\left[\mathrm{i}^{<} \mathrm{i}^{\prime} \wedge \varphi\left(\mathrm{i}^{\prime}\right)\right] \wedge \forall \mathrm{h}: \operatorname{PREF}(\text { Lising })(\mathrm{i})(\mathrm{h}) \exists \mathrm{i}^{\prime}: \mathrm{h}\left(\mathrm{i}^{\prime}\right) \varphi\left(\mathrm{i}^{\prime}\right)\right]\right]\right]
\end{aligned}
$$

This states that at an index $\mathrm{i}$ at or before $\mathrm{c}$, the histories preferred by Lising at $i$ are such that the host proposition $\varphi$, that Enet sings, becomes true at some index. In addition, $\varphi$ indeed can become true after $i$, that is, Lising does not have an unrealistic preference. Counterfactual attitudes, indeed, are expressed with a different modality, realis negation or distal. As before with predictions, the use of realis modality in buletic clauses is excluded, as this would result in conflicting conditions PREF(Lising)(i)(j), which entails $i<h$, and $\exists i^{\prime}: h\left(i^{\prime}\right)\left[i^{\prime} \leq i \wedge \ldots\right]$.

The expression of ability as in (51) is parallel to preferences, where the embedding predicate identifies a modal relation $A B L E(x)(i)$ that applies to the histories after $i$ that are compatible with the abilities of $x$ in $i$. That is, nothing happens in those histories that imply an action of $\mathrm{x}$ that $\mathrm{x}$ is not capable of at $\mathrm{i}$.

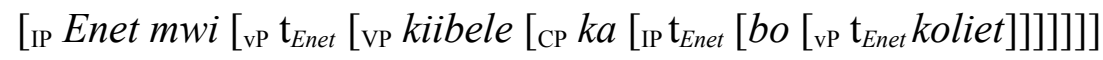
'Enet is able to sing', 'Enet knows how to sing'

\section{$\lambda \mathrm{i}\left[: \exists \mathrm{i}^{\prime}\left[\mathrm{i}<\mathrm{i}^{\prime} \varphi\left(\mathrm{i}^{\prime}\right)\right] \forall \mathrm{h}: \mathrm{ABLE}\left(\right.\right.$ Enet)(i)(h) $\left.\exists \mathrm{i}^{\prime}: \mathrm{h}\left(\mathrm{i}^{\prime}\right) \varphi\left(\mathrm{i}^{\prime}\right)\right]$}

The vP of (51) then is interpreted as in (52), which states that in all histories $h$ after the reference index $i$ that correspond to Enet's abilities at $i$, there is an index $i^{\prime}$ at which she sings. Within a branching world paradigm, this is a suitable representation of abilities: If Enet looses her abilities to sing at some index i* after i, then the indices after $i^{*}$ are not included in the histories that correspond to Enet's abilities at i. Also, notice that if Enet is able to sing at $i$ it does not follow that Enet will actually sing at some index after $i$ - the course the world is taking can follow for some while the histories in ABLE(Enet)(i), and then take a direction outside of this histories. ${ }^{4}$

4 The fact that Daakie kiibele, just like English know, expresses both doxastic and ability modals is not explained by this representation; cf. Stanley 2011 for this combination. 
Realis and non-realis modality

\section{Potentialis negation: $-n, n e$}

We have treated realis negation as expressing a presupposition that the host proposition is false, and as stating that it is false. Hence realis negation could not be used to express a prediction or a preference that a proposition will not become true, or that the subject is unable to make the proposition true. For these cases, Daakie employs a distinct modality, potentialis negation.

The negative complementizer saka is used with potentialis negation for predictions, cf. (53), preferences, cf. (54), and epistemic clauses, cf. (55).

$\boldsymbol{s a}=\boldsymbol{k a}$ ne lehe ngyo

'He will not find me.', personal story (Abel3.017)

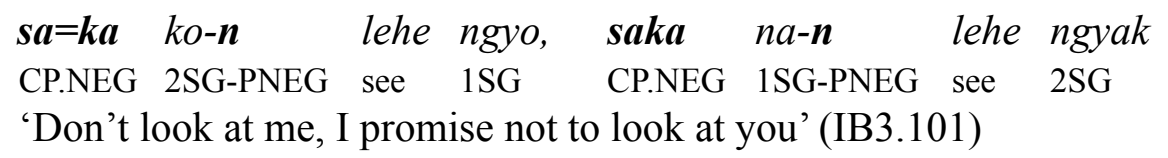

$$
\begin{aligned}
& \text { sa }=\boldsymbol{k} \boldsymbol{a} \text { ko- } \boldsymbol{n} \quad \text { lehe lokuo de-Soo } \\
& \text { CP.NEG 2SG-PNEG see leaf NRE-IDEF } \\
& \text { 'You could not see any leaves', description of eruption (Aeven4.081) }
\end{aligned}
$$

In dependent clauses, the $\mathrm{N}$ modality occurs in the scope of negated main clause verbs, cf. (56), or of verbs that imply a negation, cf. (57).

$$
\begin{array}{llll}
\text { na-re } & \text { kiibele } & \boldsymbol{k} \boldsymbol{a} \text { na-n } & \text { teli } \\
\text { 1SG-RNEG } & \text { know } & \text { CP.NR1SG-PNEG } & \text { walk } \\
\text { 'I could not walk', } & \text { personal story (Boa1.084) }
\end{array}
$$

$$
\begin{aligned}
& \text { na-m not=selaane } k \boldsymbol{k} \text { na-n gove-ne tiri de-Soo } \\
& \text { 1SG-RE think-wrongly CP.NR 1SG-PNEG do-TR something NR-IDEF } \\
& \text { 'I was unable to do anything', personal story (Boa1.47) }
\end{aligned}
$$

I propose that the $\mathrm{N}$ form is similar to the potentialis marker but comes with a falsity presupposition, cf. (58); hence the term "potentialis negation". 5

$$
\begin{aligned}
& \mathbb{[}\left[\text { IP Enet }\left[\text { ne }\left[{ }_{\mathrm{vP}} \mathrm{t}_{\text {Enet }} \text { koliet }\right]\right]\right] \rrbracket(\mathrm{c}) \\
& \left.=\lambda \mathrm{i} \lambda \mathrm{i}^{\prime}\left[: \mathrm{i}<\mathrm{i}^{\prime}: \neg \varphi\left(\mathrm{i}^{\prime}\right) \varphi\left(\mathrm{i}^{\prime}\right)\right]\right]
\end{aligned}
$$

This expression contains a contradictory component $[: \neg \Phi \Phi]$, which requires a negation to be resolved. It can be provided by the complementizer saka, cf. (59):

5 As Hedde Zeijlstra pointed out to me, this is related to the analysis of n-words like nessuno in Italian by Alonso-Ovalle \& Guerzoni (2004). According to their proposal, they are indefinites that come with the conventional implicature that their host proposition is false, hence the proposition requires a negation to become assertable. 
(59) a. $\llbracket \operatorname{saka} \rrbracket(\mathrm{c})=\lambda \mathrm{i} \lambda \mathrm{p} \forall \mathrm{h}: \mathrm{R}(\mathrm{i})(\mathrm{h}) \neg \exists \mathrm{i}^{\prime}: \mathrm{h}\left(\mathrm{i}^{\prime}\right) \mathrm{p}\left(\mathrm{i}^{\prime}\right)$

b. [[ [с saka [ір Enet ne koliet $]] \rrbracket(\mathrm{c})$

$=\lambda \mathrm{i}[\llbracket$ saka $\rrbracket(\mathrm{c})(\mathrm{i})(\llbracket[$ IP Enet ne koliet $] \rrbracket(\mathrm{c})(\mathrm{i}))]$

$\left.=\lambda \mathrm{i} \forall \mathrm{h}: \mathrm{R}(\mathrm{i})(\mathrm{h}) \neg \exists \mathrm{i}^{\prime}: \mathrm{h}\left(\mathrm{i}^{\prime}\right)\left[: \mathrm{i}<\mathrm{i}^{\prime}: \neg \varphi\left(\mathrm{i}^{\prime}\right)\right] \varphi\left(\mathrm{i}^{\prime}\right)\right]$

$=\lambda \mathrm{i} \forall \mathrm{h}: \mathrm{R}(\mathrm{i})(\mathrm{h}) \forall \mathrm{i}^{\prime}: \mathrm{h}\left(\mathrm{i}^{\prime}\right)\left[: \mathrm{i}<\mathrm{i}^{\prime}: \neg \varphi\left(\mathrm{i}^{\prime}\right) \neg \varphi\left(\mathrm{i}^{\prime}\right)\right]$

$=\lambda \mathrm{i} \forall \mathrm{h}: \mathrm{R}(\mathrm{i})(\mathrm{h}) \forall \mathrm{i}^{\prime}: \mathrm{h}\left(\mathrm{i}^{\prime}\right)\left[: \mathrm{i}<\mathrm{i}^{\prime} \wedge: \neg \varphi\left(\mathrm{i}^{\prime}\right)\right]$, cf. (3d).

c. $\llbracket[$ Forcep ASSERT [cP saka [IP Enet ne koliet]]]](c)

$=\lambda \mathrm{c}\left[\mathrm{C}(\mathrm{c}) \wedge ! \forall \mathrm{h}: \mathrm{R}(\mathrm{c})(\mathrm{h}) \forall \mathrm{i}^{\prime}: \mathrm{h}\left(\mathrm{i}^{\prime}\right)\left[: \mathrm{c}<\mathrm{i}^{\prime} \wedge: \neg \varphi\left(\mathrm{i}^{\prime}\right)\right]\right]$

$=\lambda \mathrm{c}\left[\mathrm{C}(\mathrm{c}) \wedge \forall \mathrm{h}: \mathrm{R}(\mathrm{c})(\mathrm{h}) \forall \mathrm{i}^{\prime}: \mathrm{h}\left(\mathrm{i}^{\prime}\right)\left[\mathrm{c}<\mathrm{i}^{\prime} \wedge \neg \varphi\left(\mathrm{i}^{\prime}\right)\right]\right]$

The relation $\mathrm{R}$ can be pragmatically specified by some accessibility relation, e.g. prediction FUT, preference PREF, or an epistemic relation, cf. (53), (54), (55). The condition $c<i^{\prime}$ is trivially satisfied, as for all relations $R$ with $R(c)(h), h$ is a history that starts with $\mathrm{c}$. What is crucial is that the host proposition is claimed to be false at all indices i' of all such histories $h$. This results in meanings like 'Enet will not sing', 'Enet should not sing', or 'Enet could not have sung'.

In embedded clauses, the negation that resolves the undefinedness of $\mathrm{N}$ marked clauses comes from the embedding predicate. I will show this for (60), which is interpreted up to the IP level in (61). When asserted, we arrive at (62a).

(60) [IP Enet tere [ ${ }_{\mathrm{vP}} \mathrm{t}_{\text {Enet }}$ kiibele [cP $\mathrm{ka}$ [IP $\mathrm{t}_{\text {Enet }}$ ne koliet]]]] 'Enet was not able to sing.'

(61) a. $\mathbb{[}\left[\mathrm{CP} k a\left[{ }_{\text {IP }} \mathrm{t}_{\text {Enet }}\right.\right.$ ne koliet $\left.]\right] \rrbracket(\mathrm{c})$ $=\lambda \mathrm{i}\left[\llbracket k a \rrbracket(\mathrm{c})(\mathrm{i})\left(\llbracket\left[\mathrm{IIP}_{\text {Enet }}\right.\right.\right.$ ne koliet $\left.\left.] \rrbracket(\mathrm{c})(\mathrm{i})\right)\right]$

$\left.=\lambda \mathrm{i} \lambda \mathrm{R} \forall \mathrm{h}: \mathrm{R}(\mathrm{i})(\mathrm{h}) \exists \mathrm{i}^{\prime}: \mathrm{h}\left(\mathrm{i}^{\prime}\right)\left[: \mathrm{i}<\mathrm{i}^{\prime}:\right\urcorner \varphi\left(\mathrm{i}^{\prime}\right) \varphi\left(\mathrm{i}^{\prime}\right)\right]$

b. $\llbracket\left[{ }_{\mathrm{vP}} \mathrm{t}_{\text {Enet }}\right.$ kiibele [IP $k a\left[\mathrm{CP}\left[\right.\right.$ [IP $\mathrm{t}_{\text {Enet }}$ ne koliet $\left.\left.\left.]\right]\right]\right](\mathrm{c})$

$=\lambda \mathrm{i} \forall \mathrm{h}: \operatorname{ABLE}\left(\right.$ Enet)(i)(h) $\exists \mathrm{i}^{\prime}: \mathrm{h}\left(\mathrm{i}^{\prime}\right)\left[: \mathrm{i}<\mathrm{i}^{\prime}: \neg \varphi\left(\mathrm{i}^{\prime}\right) \varphi\left(\mathrm{i}^{\prime}\right)\right]$

c. [[IP Enet tere [vp $\mathrm{t}_{\text {Enet }}$ kiibele [cP $k a\left[{ }_{\text {IP }} \mathrm{t}_{\text {Enet }}\right.$ ne koliet]]]](c)

$=\lambda \mathrm{i} \lambda \mathrm{i}^{\prime \prime}\left[: \neg \exists \mathrm{i}^{\prime \prime} \leq \mathrm{c} \forall \mathrm{h}: \operatorname{ABLE}\left(\right.\right.$ Enet)(i")(h) $\exists \mathrm{i}^{\prime}: \mathrm{h}\left(\mathrm{i}^{\prime}\right)\left[\mathrm{i}^{\prime \prime}<\mathrm{i}^{\prime}: \neg \varphi\left(\mathrm{i}^{\prime}\right) \varphi\left(\mathrm{i}^{\prime}\right)\right]$

$\left[\mathrm{i}^{\prime \prime} \leq \mathrm{i} \wedge \neg \forall \mathrm{h}: \operatorname{ABLE}\left(\right.\right.$ Enet)(i")(h) $\left.\left.\exists \mathrm{i}^{\prime}: \mathrm{h}\left(\mathrm{i}^{\prime}\right)\left[\mathrm{i}^{\prime \prime}<\mathrm{i}^{\prime}: \neg \varphi\left(\mathrm{i}^{\prime}\right) \varphi\left(\mathrm{i}^{\prime}\right)\right]\right]\right]$

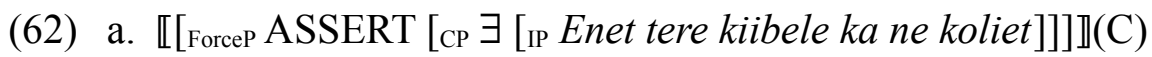
$=\lambda \mathrm{c}\left[\mathrm{C}(\mathrm{c}) \wedge !\left[: \neg \exists \mathrm{i}^{\prime \prime} \leq \mathrm{c} \forall \mathrm{h}: \mathrm{ABLE}\left(\right.\right.\right.$ Enet)(i")(h) $\exists \mathrm{i}^{\prime}: \mathrm{h}\left(\mathrm{i}^{\prime}\right)\left[\mathrm{i}^{\prime \prime}<\mathrm{i}^{\prime}: \neg \varphi\left(\mathrm{i}^{\prime}\right) \varphi\left(\mathrm{i}^{\prime}\right)\right]$ $\exists \mathrm{i}^{\prime \prime}\left[\mathrm{i}^{\prime \prime} \leq \mathrm{c} \wedge \neg \forall \mathrm{h}: \mathrm{ABLE}\left(\right.\right.$ Enet) $\left.\left.\left.\left(\mathrm{i}^{\prime \prime}\right)(\mathrm{h}) \exists \mathrm{i}^{\prime}: \mathrm{h}\left(\mathrm{i}^{\prime}\right)\left[: \mathrm{i}^{\prime \prime}<\mathrm{i}^{\prime}: \neg \varphi\left(\mathrm{i}^{\prime}\right) \varphi\left(\mathrm{i}^{\prime}\right)\right]\right]\right]\right]$

b. $=\lambda \mathrm{c}\left[\mathrm{C}(\mathrm{c}) \wedge !\left[: \forall \mathrm{i}^{\prime \prime} \leq \mathrm{c} \neg \forall \mathrm{h}: \operatorname{ABLE}\left(\right.\right.\right.$ Enet)(i")(h) $\exists \mathrm{i}^{\prime}: \mathrm{h}\left(\mathrm{i}^{\prime}\right)\left[\mathrm{i}^{\prime \prime}<\mathrm{i}^{\prime}: \neg \varphi\left(\mathrm{i}^{\prime}\right) \varphi\left(\mathrm{i}^{\prime}\right)\right]$ $\exists \mathrm{i}^{\prime \prime}\left[\mathrm{i}^{\prime \prime} \leq \mathrm{c} \wedge \exists \mathrm{h}: \mathrm{ABLE}\left(\right.\right.$ Enet)(i")(h) $\left.\left.\neg \exists \mathrm{i}^{\prime}: \mathrm{h}\left(\mathrm{i}^{\prime}\right)\left[: \mathrm{i}^{\prime \prime}<\mathrm{i}^{\prime}: \neg \varphi\left(\mathrm{i}^{\prime}\right) \varphi\left(\mathrm{i}^{\prime}\right)\right]\right]\right]$

c. $=\lambda \mathrm{c}\left[\mathrm{C}(\mathrm{c}) \wedge\right.$ ! [: $\forall \mathrm{i}^{\prime \prime} \leq \mathrm{c} \exists \mathrm{h}: \operatorname{ABLE}(\mathrm{Enet})\left(\mathrm{i}^{\prime \prime}\right)(\mathrm{h}) \neg \exists \mathrm{i}^{\prime}: \mathrm{h}\left(\mathrm{i}^{\prime}\right)\left[\mathrm{i}^{\prime \prime}<\mathrm{i}^{\prime}: \neg \varphi\left(\mathrm{i}^{\prime}\right) \varphi\left(\mathrm{i}^{\prime}\right)\right]$ $\exists \mathrm{i}^{\prime \prime}\left[\mathrm{i}^{\prime \prime} \leq \mathrm{c} \wedge \exists \mathrm{h}: \operatorname{ABLE}\left(\right.\right.$ Enet)(i")(h) $\left.\left.\forall \mathrm{i}^{\prime}: \mathrm{h}\left(\mathrm{i}^{\prime}\right)\left[\mathrm{i}^{\prime \prime}<\mathrm{i}^{\prime}: \neg \varphi\left(\mathrm{i}^{\prime}\right) \neg \varphi\left(\mathrm{i}^{\prime}\right)\right]\right]\right]$ 
Realis and non-realis modality

$$
\begin{aligned}
& \text { d. }=\lambda \mathrm{c}\left[\mathrm { C } ( \mathrm { c } ) \wedge ! \left[: \forall \mathrm{i}^{\prime \prime} \leq \mathrm{c} \exists \mathrm{h}: \operatorname{ABLE}(E n e t)\left(\mathrm{i}^{\prime \prime}\right)(\mathrm{h}) \forall \mathrm{i}^{\prime}: \mathrm{h}\left(\mathrm{i}^{\prime}\right)\left[: \mathrm{i}^{\prime \prime}<\mathrm{i}^{\prime} \wedge: \neg \varphi\left(\mathrm{i}^{\prime}\right)\right]\right.\right. \\
& \left.\exists \mathrm{i}^{\prime \prime}\left[\mathrm{i}^{\prime \prime} \leq \mathrm{c} \wedge \exists \mathrm{h}: \operatorname{ABLE}(\text { Enet })\left(\mathrm{i}^{\prime \prime}\right)(\mathrm{h}) \forall \mathrm{i}^{\prime}: \mathrm{h}\left(\mathrm{i}^{\prime}\right)\left[: \mathrm{i}^{\prime \prime}<\mathrm{i}^{\prime} \wedge: \neg \varphi\left(\mathrm{i}^{\prime}\right)\right]\right]\right] \\
& \text { e. }=\lambda \mathrm{c}\left[\mathrm{C}(\mathrm{c}) \wedge !\left[: \forall \mathrm{i}^{\prime \prime} \leq \mathrm{c} \exists \mathrm{h}: \operatorname{ABLE}(\text { Enet })\left(\mathrm{i}^{\prime \prime}\right)(\mathrm{h}) \forall \mathrm{i}^{\prime}: \mathrm{h}\left(\mathrm{i}^{\prime}\right)\left[: \mathrm{i}^{\prime \prime}<\mathrm{i}^{\prime} \wedge: \neg \varphi\left(\mathrm{i}^{\prime}\right)\right]\right]\right] \\
& \text { f. }=\lambda \mathrm{c}\left[\mathrm { C } ( \mathrm { c } ) \wedge ! \left[: \forall \mathrm{i}^{\prime \prime} \leq \mathrm{c}\left[: \forall \mathrm{h}: \operatorname{ABLE}(\text { Enet })\left(\mathrm{i}^{\prime \prime}\right)(\mathrm{h}) \forall \mathrm{i}^{\prime}: \mathrm{h}\left(\mathrm{i}^{\prime}\right)\left[\mathrm{i}^{\prime \prime}<\mathrm{i}^{\prime} \wedge \neg \varphi\left(\mathrm{i}^{\prime}\right)\right]\right.\right.\right. \\
& \left.\left.\exists \text { h: ABLE(Enet)(i")(h) } \forall \mathrm{i}^{\prime}: \mathrm{h}\left(\mathrm{i}^{\prime}\right)\left[\mathrm{i}^{\prime \prime}<\mathrm{i}^{\prime} \wedge \neg \varphi\left(\mathrm{i}^{\prime}\right)\right]\right]\right] \\
& \text { g. }=\lambda \mathrm{c}\left[\mathrm{C}(\mathrm{c}) \wedge \forall \mathrm{i}^{\prime \prime} \leq \mathrm{c} \forall \mathrm{h}: \operatorname{ABLE}(\text { Enet })\left(\mathrm{i}^{\prime \prime}\right)(\mathrm{h}) \forall \mathrm{i}^{\prime}: \mathrm{h}\left(\mathrm{i}^{\prime}\right)\left[\mathrm{i}^{\prime \prime}<\mathrm{i}^{\prime} \wedge \neg \varphi\left(\mathrm{i}^{\prime}\right)\right]\right.
\end{aligned}
$$

We get from (62a) to (b) by the equivalences $\neg \exists \mathrm{i}^{\prime \prime} \ldots \forall \mathrm{h} . . . \equiv \forall \mathrm{i}^{\prime \prime} \ldots \neg \forall \mathrm{h} . .$. and $\neg \forall \mathrm{h}: . . \exists \mathrm{i}^{\prime} \ldots \equiv \exists \mathrm{h}: . . . \neg \exists \mathrm{i}^{\prime} \ldots$, and similarly to (c) and (d). The negation "trickles down" to the N-marked IP, resolving the contradiction between presupposition and host proposition. The simplification (e) is possible as the presupposition entails the non-presupposed part. In (f), the presupposition in the scope of $\exists$ h:... is projected, following (5b). This leads to the proper interpretation that for all histo ries $h$ that represent the abilities of Enet at any index $i^{\prime \prime}$ at or before $c, h$ does not contain an index of Enet singing. The projection rule for presuppositions $(5 b)$ is essential for turning the existential negation of the embedding clause into a universal negation. For negative-implying verbs like notselaane 'to think wrongly' we would have to assume negation as part of the lexical-semantic representation.

\section{Distal -t / t $(V)$}

The distal form is used as a temporal scene setter, either as an independent clause for the following discourse, cf. (63), or as an adjunct clause, cf. (64).

(63) meerin témat la-t pwee long.ago zombies 3PL-DST be.many 'Long ago, there were many zombies.' (Boa3.025)

$$
\begin{array}{lllllll}
\text { yaa te } & \text { van } & \text { te } & \text { pwet ti piipili } & \text { mwe kuoli=mee tyenem } \\
\text { [sun DST go } & \text { DST } & \text { PROG DST red] } & \text { RE return=come home }
\end{array}
$$

'When the sun became red (in the evening), he went home' (Ilson2.021)

The distal occurs in complement clauses embedded by propositional attitude verbs when it is implicated that they are in fact false, cf. (65), (66).

$$
\begin{aligned}
& \text { kye-m deme } \boldsymbol{k a} \text { te we mee gon ngi-ye } \\
& \text { 3PC-RE think CP.NR DST fruit.TR dragonplum FOC FOC-PROX } \\
& \text { 'They thought that they were just dragonplum fruits' (Wili1.030) }
\end{aligned}
$$

(66) mo gotó-ne $\boldsymbol{k a}$ te mese baabap ten

RE make-TR CP.NR DST sick very much

'He pretended to be very sick', translation (Aesop094) 
I propose that the distal expresses no relation between event and reference in dex, with the possible exception that the event index cannot be the context.
a. $\llbracket-t \rrbracket(c)=\lambda \mathrm{i} \lambda \mathrm{i}^{\prime} \lambda \mathrm{p}\left[\mathrm{i}^{\prime} \neq \mathrm{c} \mathrm{p}\left(\mathrm{i}^{\prime}\right)\right]$
b. $\mathbb{[}[\mathrm{IP}$ Enet te koliet $] \rrbracket(\mathrm{c})=\lambda \mathrm{i} \lambda \mathrm{i}^{\prime}\left[\mathrm{i}^{\prime} \neq \mathrm{c} \varphi\left(\mathrm{i}^{\prime}\right)\right]$

In distal main clauses as in (63), the relation between event time and reference time is restricted by a temporal adverbial, preferably meerin 'long time ago'; this also sets an anaphoric anchor for the event index of the following clauses.

$\mathbb{\llbracket}[\mathrm{IP}$ meerin [ip Enet te koliet $]]](\mathrm{c})$ $=\lambda \mathrm{i} \lambda \mathrm{i}^{\prime}\left[\llbracket\right.$ meerin $\rrbracket(\mathrm{c})(\mathrm{i})\left(\mathrm{i}^{\prime}\right) \wedge \llbracket[$ Ir Enet te koliet $\left.] \rrbracket(\mathrm{c})(\mathrm{i})\left(\mathrm{i}^{\prime}\right)\right]$

$=\lambda \mathrm{i} \lambda \mathrm{i}^{\prime}\left[\mathrm{i}^{\prime}<<\mathrm{c} \wedge\left[: \mathrm{i}^{\prime} \neq \mathrm{c} \varphi\left(\mathrm{i}^{\prime}\right)\right]\right]$ (with $\mathrm{i}^{\prime}$ a topic time for following clauses)

In (68), the topic time is specified within a clause. I assume that such specifications of topic times are presupposed. We will discuss this with example (69).

[Forcep ASSERT [ст $\exists$ [[ip Enet te koliet] [IP Lising mwe sap]]] 'When Enet sang, Lising was dancing.'

The distal clause indicates the topic time. This can be interpreted by a conjunction of two propositional relations, as in (70). It is the event indices of the two clauses that are related to each other, not the reference indices, hence the relation between the indices are expressed within the IP. After existential closure and as sertion at $\mathrm{C}$, we arrive at the common ground (71).

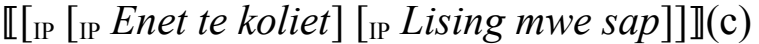

$$
\begin{aligned}
& =\lambda \mathrm{i} \lambda \mathrm{i}^{\prime}\left[: \mathbb{[}[\text { IP Enet te koliet }] \rrbracket(\mathrm{c})(\mathrm{i})\left(\mathrm{i}^{\prime}\right) \wedge \mathbb{\llbracket}[\text { IP Lising mwe sap }] \rrbracket(\mathrm{c})(\mathrm{i})\left(\mathrm{i}^{\prime}\right)\right] \\
& =\lambda \mathrm{i} \lambda \mathrm{i}^{\prime}\left[:\left[\mathrm{i}^{\prime} \neq \mathrm{c} \wedge \varphi\left(\mathrm{i}^{\prime}\right)\right] \wedge\left[: \exists \mathrm{i}^{\prime}\left[\mathrm{i}^{\prime} \leq \mathrm{c} \wedge \psi\left(\mathrm{i}^{\prime}\right)\right]\left[\mathrm{i}^{\prime} \leq \mathrm{i} \psi\left(\mathrm{i}^{\prime}\right)\right]\right]\right] \\
& =\lambda \mathrm{i} \lambda \mathrm{i}^{\prime}\left[\mathrm{i}^{\prime}<\mathrm{i}: \varphi\left(\mathrm{i}^{\prime}\right): \exists \mathrm{i}^{\prime}\left[\mathrm{i}^{\prime} \leq \mathrm{c} \wedge \psi\left(\mathrm{i}^{\prime}\right)\right] \psi\left(\mathrm{i}^{\prime}\right)\right]
\end{aligned}
$$

$$
\llbracket(68) \rrbracket(C)=\lambda c\left[C(c) \wedge \exists i^{\prime}\left[i^{\prime}<c \wedge \varphi\left(i^{\prime}\right) \wedge \psi\left(i^{\prime}\right)\right]\right]
$$

We turn to distal modality in embedded clauses, which I will discuss with example (72). The embedding predicate deme expresses a doxastic accessibility relation for histories, where $\operatorname{DOX}(\mathrm{x})(\mathrm{i})(\mathrm{h})$ holds if $\mathrm{h}$ is a history in which nothing happens that is contrary to the beliefs of $x$ at $h$. In contrast to $\operatorname{DOX}(x)(i)\left(i^{\prime}\right)$ for kiibele, cf. (20), this is not understood as a belief about the index i. This leads to interpretation in (73). Crucially, deme does not introduce a factivity presupposition, different from kiibele. This makes embedded distal clauses applicable in cases in which they are in fact not true, as in (65) and (66).

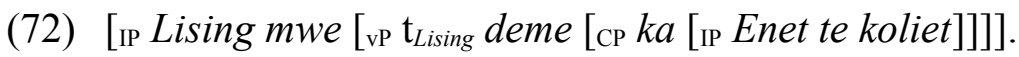

'Lising thinks/thought that Enet is singing/was singing/will be singing' 
Realis and non-realis modality

(73)

a. $\mathbb{[}[\mathrm{CP} k a[$ IP Enet te koliet $]] \rrbracket(\mathrm{c})$

$=\lambda \mathrm{i}[\llbracket k a \rrbracket(\mathrm{c})(\mathrm{i})(\llbracket[$ IP Enet te koliet $] \rrbracket(\mathrm{c})(\mathrm{i}))]$

$\left.=\lambda \mathrm{i}\left[\lambda \mathrm{p} \lambda \mathrm{R} \forall \mathrm{h}: \mathrm{R}(\mathrm{i})(\mathrm{h}) \exists \mathrm{i}^{\prime}: \mathrm{h}\left(\mathrm{i}^{\prime}\right) \mathrm{p}\left(\mathrm{i}^{\prime}\right)\right]\left(\lambda \mathrm{i}^{\prime}\left[: \mathrm{i}^{\prime} \neq \mathrm{c} \varphi\left(\mathrm{i}^{\prime}\right)\right]\right)\right]$

$=\lambda \mathrm{i} \lambda \mathrm{R} \forall \mathrm{h}: \mathrm{R}(\mathrm{i})(\mathrm{h}) \exists \mathrm{i}^{\prime}: \mathrm{h}\left(\mathrm{i}^{\prime}\right)\left[\mathrm{i}^{\prime} \neq \mathrm{c} \varphi\left(\mathrm{i}^{\prime}\right)\right]$

b. $\llbracket\left[{ }_{\mathrm{vp}}\right.$ Lising deme $[\mathrm{ka}[\mathrm{IP}$ Enet te koliet $\left.]]\right] \rrbracket(\mathrm{c})$

$=\lambda \mathrm{i} \forall \mathrm{h}: \operatorname{DOX}(\operatorname{Lising})(\mathrm{i})(\mathrm{h}) \exists \mathrm{i}^{\prime}: \mathrm{h}\left(\mathrm{i}^{\prime}\right)\left[: \mathrm{i}^{\prime} \neq \mathrm{c} \varphi\left(\mathrm{i}^{\prime}\right)\right]$

Distal is also used to express the protasis of conditional clauses. In the apodosis, we find either potentialis or, in the case of counterfactuals, the marker $a+$ distal, as in examples (74) and (75) that simulate a situation in which the addressee places a bet by choosing between one of two fruits.

ko-t pyak soro $k a$ tu wuo, a-ko-p idi popat.

2SG-DST choose reach CR.NR DST good FUT-2SG-POT take pig

'In case you choose well, you will win a pig.' (elicited)

\section{ka ko-t pyak-ne vih, a-ko-t idi popat \\ CR.NR 2SG-DST choose-TR banana FUT-2SG-DST take pig \\ 'If you had chosen the banana, you would have won the pig.' (elicited)}

We arrive at a suitable interpretation when the quantification expressed by the future marker $a$ - and the complementizer $k a$ is restricted to those indices for which the sentence is defined (cf. (2)(b) for \$), as in (76), where R is FUT for $a^{-}$.

$$
\llbracket(k) a-\rrbracket(\mathrm{c})=\lambda \mathrm{i} \lambda \mathrm{r} \forall \mathrm{h}:\left[\mathrm{R}(\mathrm{i})(\mathrm{h}) \wedge \exists \mathrm{i}^{\prime}: \mathrm{h}\left(\mathrm{i}^{\prime}\right) \$ \mathrm{r}(\mathrm{i})\left(\mathrm{i}^{\prime}\right)\right] \exists \mathrm{i}^{\prime}: \mathrm{h}\left(\mathrm{i}^{\prime}\right) \mathrm{r}(\mathrm{i})\left(\mathrm{i}^{\prime}\right)
$$

Example (74) is illustrated by (77), meaning 'if Enet sings, Lising will dance'. FUT(i) is restricted to histories for which the presuppositions are satisfied; this means crucially those histories for which the te clause holds. We get an "indicative" conditional, as the apodosis can become true due to its potentialis marking.

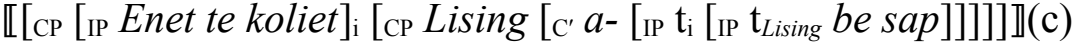

$$
\begin{aligned}
& =\lambda \mathrm{i}[\llbracket a-\rrbracket(\mathrm{c})(\mathrm{i})([\mathbb{[}[\mathrm{IP} \text { [IP Enet te koliet }] \text { [IP Lising be sap }]] \rrbracket(\mathrm{c}))] \\
& =\lambda \mathrm{i} \forall \mathrm{h}:\left[\mathrm{FUT}(\mathrm{i})(\mathrm{h}) \wedge \exists \mathrm{i}^{\prime}: \mathrm{h}\left(\mathrm{i}^{\prime}\right) \$\left[: \mathrm{i}^{\prime} \neq \mathrm{c}: \varphi\left(\mathrm{i}^{\prime}\right): \exists \mathrm{i}^{\prime}\left[\mathrm{i}<\mathrm{i}^{\prime} \wedge \psi\left(\mathrm{i}^{\prime}\right)\right] \psi\left(\mathrm{i}^{\prime}\right)\right]\right] \\
& \exists i^{\prime}: h\left(i^{\prime}\right)\left[: i^{\prime} \neq c: \varphi\left(i^{\prime}\right): \exists i^{\prime}\left[i<i^{\prime} \wedge \psi\left(i^{\prime}\right)\right] \psi\left(i^{\prime}\right)\right] \\
& =\lambda \mathrm{i}\left[: \exists \mathrm{i}^{\prime}\left[\mathrm{i}<\mathrm{i}^{\prime} \wedge \psi\left(\mathrm{i}^{\prime}\right)\right] \forall \mathrm{h}:\left[\mathrm{FUT}(\mathrm{i})(\mathrm{h}) \wedge \exists \mathrm{i}^{\prime}: \mathrm{h}\left(\mathrm{i}^{\prime}\right)\left[\mathrm{i}^{\prime} \neq \mathrm{c} \wedge \varphi\left(\mathrm{i}^{\prime}\right) \wedge \exists \mathrm{i}^{\prime}\left[\mathrm{i}^{\prime}<\mathrm{i}^{\prime} \wedge \psi\left(\mathrm{i}^{\prime}\right)\right]\right]\right]\right. \\
& \left.\exists i^{\prime}: h\left(i^{\prime}\right)\left[: i^{\prime} \neq c: \varphi\left(i^{\prime}\right) \psi\left(i^{\prime}\right)\right]\right]
\end{aligned}
$$

Example (75) can be interpreted as illustrated by (78), meaning 'if Enet had sung, Lising would have danced'. The apodosis carries a distal marking, hence an interpretation that does not presuppose that it may become true, which makes it similar to a counterfactual conditional. The representation takes $a$ - to be a separate modal marker for future, and simplifies a bit for reasons of space. The resulting proposition applies to indices $\mathrm{i}(=\mathrm{c})$ such that every history $\mathrm{h}$ compatible with the accessibility relation $\mathrm{R}$ for which there is an index $\mathrm{i}^{\prime}$ at which Enet sings is also a 
history for which there is an index $i^{\prime}$ at which Enet sings that is predicted to have a subsequent index $i^{\prime \prime}$ at which Lising dances.

(78) $\mathbb{\llbracket [ \mathrm { CP }}\left[k a\left[{ }_{\text {IP }}\right.\right.$ [IP Enet te koliet $]$ [CP Lising $a-{ }_{\text {IP }} \mathrm{t}_{\text {Lising }}$ te sap $\left.\left.\left.\left.]\right]\right]\right]\right](\mathrm{c})$ $=\lambda \mathrm{i}\left[\llbracket k a \rrbracket(\mathrm{c})\left(\lambda \mathrm{i}^{\prime}\left[: \llbracket[\right.\right.\right.$ IP Enet te koliet $] \rrbracket(\mathrm{c})(\mathrm{i})\left(\mathrm{i}^{\prime}\right)\left(\llbracket[\mathrm{cP}\right.$ Lising a-te sap $\left.\left.] \rrbracket(\mathrm{c})\left(\mathrm{i}^{\prime}\right)\right)\right]$

$=\lambda \mathrm{i} \forall \mathrm{h}:\left[\mathrm{R}(\mathrm{i})(\mathrm{h}) \wedge \exists \mathrm{i}^{\prime}: \mathrm{h}\left(\mathrm{i}^{\prime}\right) \$\left[: \varphi\left(\mathrm{i}^{\prime}\right) \forall \mathrm{h}^{\prime}: \mathrm{FUT}\left(\mathrm{i}^{\prime}\right)\left(\mathrm{h}^{\prime}\right) \exists \mathrm{i}^{\prime \prime}: \mathrm{h}^{\prime}\left(\mathrm{i}^{\prime \prime}\right) \psi\left(\mathrm{i}^{\prime \prime}\right)\right]\right]$ $\exists \mathrm{i}^{\prime}: \mathrm{h}\left(\mathrm{i}^{\prime}\right)\left[: \varphi\left(\mathrm{i}^{\prime}\right) \forall \mathrm{h}^{\prime}: \mathrm{FUT}\left(\mathrm{i}^{\prime}\right)\left(\mathrm{h}^{\prime}\right) \exists \mathrm{i}^{\prime \prime}: \mathrm{h}^{\prime}\left(\mathrm{i}^{\prime \prime}\right) \psi\left(\mathrm{i}^{\prime \prime}\right)\right]$

$=\lambda \mathrm{i} \forall \mathrm{h}:\left[\mathrm{R}(\mathrm{i})(\mathrm{h}) \wedge \exists \mathrm{i}^{\prime}:\left[\mathrm{h}\left(\mathrm{i}^{\prime}\right) \wedge \varphi\left(\mathrm{i}^{\prime}\right)\right]\right]$ $\exists \mathrm{i}^{\prime}: \mathrm{h}\left(\mathrm{i}^{\prime}\right)\left[: \varphi\left(\mathrm{i}^{\prime}\right) \forall \mathrm{h}^{\prime}:\right.$ FUT( $\left.\left(\mathrm{i}^{\prime}\right)\left(\mathrm{h}^{\prime}\right) \exists \mathrm{i}^{\prime \prime}: \mathrm{h}\left(\mathrm{i}^{\prime \prime}\right) \psi\left(\mathrm{i}^{\prime \prime}\right)\right]$

While the distal is a relatively rare marker, it is semantically the least specified, and hence can be used in case the conditions for realis and potentials would not be met because they would introduce unwarranted presuppositions.

\section{References}

Alonso-Ovalle, Luis \& Elena Guerzoni. 2004. Double negation, negative concord and metalinguistic negation. In Mary Andronis et al. (eds.), Chicago Linguistic Society (CLS) 38, 15-31. Chicago: CLS Publications.

Beaver, David Ian. 1997. Presupposition. In Johan van Benthem, Johan \& Alice ter Meulen (eds), Handbook of Logic and Language, 939-1008. Elsevier.

de Haan, Ferdinand. 2012. Irrealis: Fact or fiction? Language Sciences 34, 107130.

Dowty, David R. 1977. Toward a semantic analysis of verb aspect and the English 'imperfective' progressive. Linguistics and Philosophy 1, 45-77.

Gajewski, Jon. 2002. L-Analyticity and natural language. Ms., Cambridge, MA. See http://gajewski.uconn.edu/research.html?.

Krifka, Manfred. 2012. Notes on Daakie (Ambrym, Vanuatu): Sounds and modality. Austronesian Formal Linguistics Association (AFLA) 18, 46-65. Cambridge, MA: Harvard University.

Partee, Barbara. 1973. Some analogies between tenses and pronouns in English. Journal of Philosophy 70, 601-609.

Stanley, Jason. 2011. Knowing (how). Nous 45, 207-238.

von Prince, Kilu. 2015. A Grammar of Daakaka. Berlin: Mouton de Gruyter.

Manfred Krifka

IdSL

Humboldt-Universität zu Berlin

D-10099 Berlin, Germany

krifka@rz.hu-berlin.de
Zentrum für Allgemeine Sprachwissenschaft

(ZAS)

Schützenstraße 18

D-10117 Berlin, Germany 